\title{
Modelling the shelf circulation off eastern Tasmania
}

\author{
Eric C. J. Oliver ${ }^{\mathrm{a}, \mathrm{b}, *}$, Mike Herzfeld ${ }^{\mathrm{c}}$, Neil J. Holbrook ${ }^{\mathrm{a}, \mathrm{b}}$, \\ ${ }^{a}$ Institute for Marine and Antarctic Studies, University of Tasmania, Hobart TAS, Australia \\ ${ }^{b}$ Australian Research Council Centre of Excellence for Climate System Science, University of Tasmania, \\ Hobart TAS, Australia \\ ${ }^{c}$ CSIRO Oceans and Atmosphere, Hobart TAS, Australia
}

\begin{abstract}
The marine waters across Tasmanian's eastern continental shelf are biologically productive and home to economically important fisheries and aquaculture industries. However, the marine climate there is poorly understood. We use a high-resolution $(\sim 2 \mathrm{~km}$ in the horizontal), three-dimensional ocean model for eastern Tasmania (ETAS) to examine the simulated mean state and seasonal cycle of temperature, salinity and three-dimensional flow field, and the evaluation of daily model outputs against in situ and remote observations for the 1993-2014 period. We also use the model to examine the roles of river input and tidal forcing. The model is evaluated against remotely-sensed sea surface temperature and in-situ observations of sea level and subsurface temperature, salinity, and currents. The mean state demonstrates the influence of two well-known boundary currents (the East Australian Current, EAC, and the Zeehan Current, ZC) as well as the effects of local freshwater input from river runoff. The $\mathrm{EAC}$ is dominant in summer and the $\mathrm{ZC}$ in winter; the influence of the EAC also increases northwards and in the offshore direction. In addition, the model indicates the presence of a semi-permanent subsurface (50-100 m depth) northward flow trapped near the coast. Cool freshwater runoff from the Derwent and Huon Rivers directly impacts the temperature and salinity in their estuaries but has little influence further across the shelf. Tidal forcing impacts the mean state through tide-river interactions which flush Frederick Henry Bay and Norfolk Bay with freshwater. Tidal forcing also impacts the variability of temperature all
\end{abstract}

\footnotetext{
${ }^{*}$ Corresponding author

Email address: eric.oliver@utas.edu.au (Eric C. J. Oliver)
} 
along the coastline, most likely due to changes in the turbulent mixing near to the coast. The ETAS model output data are available as a high-resolution representation of the mean state, seasonal variations, and interannual variability of Tasmania's eastern continental shelf marine climate.

Keywords: ocean modeling, continental shelf circulation, seasonal variability, Tasmania, boundary current, seasonal cycle

\section{Introduction}

The waters over the continental shelf off eastern Tasmania, an island state off southeast Australia, are biologically productive and support large-scale fisheries and aquaculture industries including abalone (Mayfield et al., 2012), rock lobster (Pecl et al., 2009), and Atlantic salmon (ABARE, 2014). Coastal and continental shelf waters off eastern Tasmania form the southeastern-most portion of the 'Great Southern Reef', an $8000 \mathrm{~km}$ temperate reef system and global biodiversity hotspot, which in Tasmania accounts for $14 \%$ of expenditures by the regional tourism industry (Bennett et al., 2015). The wild abalone fishery in southern 9 Tasmania alone is worth AUD $\$ 100$ million per year (Bennett et al., 2015). Unfortunately, the near-shore and continental shelf oceanography remain poorly understood. Historically, observations in the nearshore have been limited to data obtained from a single long-term monitoring site at Maria Island, although more recently the observing system has improved in spatial coverage with access to satellite remotely-sensed surface temperatures and heights, additional monitoring stations, and subsurface glider operations. Many of these efforts have been spearheaded by the Integrated Marine Observing system (IMOS). Nonetheless, there remains a need to improve our understanding of the regional circulation and distribution of temperature and salinity, particularly in light of climate variability and long-term change, for which this region is a hotspot exhibiting warming at 3-4 times the global-average rate (Holbrook and Bindoff, 1997; Ridgway, 2007a).

The waters around Tasmania are a mix of subtropical and subantarctic origin with strong seasonal variations (Figure 1a; Harris et al. (1987)). Wyrtki (1960) made some early maps of the surface circulation around Australia and noted that eastern Tasmania was where 
subantarctic water, dominant off southwestern Tasmania (labelled as part of the West Wind Drift and later identified as the Zeehan Current (ZC; Baines et al. (1983)), met southward flowing subtropical water from the northeast of Tasmania (the East Australian Current (EAC) Extension). Wyrtki (1960) also noted that there is a seasonal circulation in the subtropical convergence, where these two water masses meet, which lies furthest north in the winter and furthest south in the summer. Harris et al. (1987) noted that Maria Island lies at the boundary between subantarctic and subtropical waters and that offshore waters are highly variable and dominated by mesoscale, frontal features. Using tracks from drifters released around the Tasmanian continental shelf, remotely-sensed sea surface temperature (SST), and in-situ observations from ships and moorings, Cresswell (2000) found an interplay between the Zeehan Current and the East Australian Current off southeastern Tasmania whereby the point of contact between the two currents lies around Schouten Island in winter and the southern tip of Tasmania in summer (see Figure 1a). Using remotely-sensed satellitebased measurements of sea level, Ridgway (2007b) confirmed the seasonal variation between the EAC and ZC, with the influence of the EAC peaking in December through March and the ZC in June--July. Ridgway (2007b) showed that the northward flow of the ZC in winter extends right up the east coast of Tasmania. Middleton and Cirano (2005) identified the ZC as having a transport of about $1 \mathrm{~Sv}$ during winter, extending to $500 \mathrm{~m}$ depth, and reaching northward along the east coast of Tasmania as far as $41.5^{\circ} \mathrm{S}-43^{\circ} \mathrm{S}$ before being swept offshore due to interactions with the EAC.

Ocean models developed to date that include this region are either too large-scale to resolve near-shore processes well or are small-domain regional models which focus on a particular portion of the Tasmanian shelf. The Bluelink system, including the Bluelink ReANalysis (BRAN; Schiller et al. (2008); Oke et al. (2013)), is a near-global ocean modeling system that provides estimates of ocean variability around Australia at $1 / 10^{\circ}$ horizontal resolution. While this is high-resolution for large- to global-scale simulations, it is nevertheless too coarse to resolve the key processes that are important for our understanding of coastal marine system dynamics over the continental shelf, such as the interaction between the ZC and the 



Figure 1: Study region, bathymetry and model domain. (a) Southeastern Australia including a schematic of the regional circulation. The grey outline indicates the ocean model domain. (b) The model domain (grey line) and bathymetry (colours) in the model study region. Dots indicate in-situ validation observations and dashed lines indicate cross-shelf sections used later in the analysis. (c) Model grid (only every second grid line is plotted) along with mean horizontal grid resolution in $\mathrm{km}$ (colours).

EAC, and cross-shelf exchanges that affect coastal marine ecology. Fine-scale models with horizontal resolution as fine as $100 \mathrm{~m}$ have been developed for the D'Entrecasteaux Channel and Huon Estuary (Herzfeld et al., 2010a) and for a significant portion of the continental shelf off southeastern Tasmania (Jones et al., 2012), but these models are focussed on the near-shore environment and have domains too small to capture shelf-scale variability, and they have not been used to simulate the long-term mean or interannual variability. Taking a different approach, Oliver and Holbrook (2014) used a statistical technique to downscale SST around the Tasmanian continental shelf, but this technique does not resolve subsurface temperature nor does it provide estimates of the circulation or salinity.

In this paper, we use a high-resolution ( $\sim 2 \mathrm{~km}$ horizontal resolution), three-dimensional ocean model for the continental shelf and slope off eastern Tasmania (ETAS) to dynamically downscale the coarser resolution Bluelink ReANalysis and better estimate the shelf circulation and distribution of temperature and salinity over the 1993-2014 period. The model simulated outputs of temperature and salinity are also evaluated on daily to seasonal to 
interannual time scales against in situ and remotely sensed observations. This model is used to map out the mean state and seasonal cycle of the marine climate of the eastern Tasmanian continental shelf and examine the roles of river input and tidal forcing in setting this state. This represents the first known attempt to model the circulation of Tasmania's entire eastern continental shelf at spatial scales that are relevant to ecological variability and over a time period long enough to capture interannual variability.

\section{Ocean model and data}

In this section the numerical ocean model is described (Section 2.1) followed by the data sources and methods used for model evaluation (2.2).

\subsection{Numerical ocean model}

The Sparse Hydrodynamic Ocean Code (SHOC) developed by Herzfeld (2006) and Herzfeld et al. (2010b) at the CSIRO Marine Laboratories in Hobart (Australia) was used to dynamically simulate variability of the near-shore and continental shelf waters off eastern Tasmania. SHOC is based on the nonlinear three-dimensional equations for momentum conservation, continuity, and the conservation of heat and salt and employs the hydrostatic and Boussinesq approximations. The use of a sparse coordinate system, which maps all cells in threedimensional space onto a one-dimensional vector, leads to efficient computation particularly for complex model domains with many dry cells as it is essentially an unstructured coordinate system transplanted in a finite difference model. SHOC has been used previously to model the D'Entrecaseaux Channel and the Huon Estuary in Tasmania (Herzfeld et al., 2010a), southeastern Tasmania (Jones et al., 2012), Moreton Bay in Queensland (Herzfeld et al., 2012), Southeast Queensland (Herzfeld and Andrewartha, 2012), and the Great Barrier Reef region (http://www.ereefs.org.au/). However, it has not previously been used to investigate the circulation along the entire eastern shelf of Tasmania, or for regional climate studies in this region.

The model domain consisted of the continental shelf and slope off eastern Tasmania (Figure 1b). The domain was defined by a curvilinear horizontal grid with three open 
boundaries and the fourth side bounded by the Tasmanian coast. The seaward boundary ran parallel to the continental shelf break roughly following the $2500 \mathrm{~m}$ isobath. The two cross-shelf boundaries ran perpendicular to the shelf break and met the coast at South Cape in the south and just north of Eddystone Point in the north. The grid included two narrow spurs for the Derwent River and Huon River estuaries.

The orthogonal curvilinear model grid consisted of 200 grid points in the $x_{1}$ (along-shelf) direction by 120 grid points in the $x_{2}$ (cross-shelf) direction (a total of 2400 grid cells in the horizontal). Model resolution varied in space from less than $1 \mathrm{~km}$ in the estuaries to $\sim 3.5$ $\mathrm{km}$ in the South and East where the grid flared out (Figure 1c); the average grid resolution was $1.9 \mathrm{~km}$. The bathymetry was averaged onto the model grid from the $1 / 100^{\circ}$ Australian Geological Survey Organisation (AGSO) 2002 bathymetry. This was supplemented by the SETAS model bathymetry (John Andrewartha, CSIRO, pers. comm.; Jones et al. (2012)) in the overlap region around southeastern Tasmania. A maximum gradient condition of 0.06 was imposed to assist stability and the bathymetry was locally smoothed until this condition was satisfied. The model variables were defined in the horizontal following an Arakawa C-grid. The model had a maximum of 44 -levels in the vertical with partial cells at the bottom (no smaller than $20 \%$ of the grid layer thickness). Level thickness increased from $1 \mathrm{~m}$ near the surface to a maximum of $230 \mathrm{~m}$ for the bottom-most level. The maximum (minimum) depth is $2500 \mathrm{~m}(2 \mathrm{~m})$. Only $30 \%$ of the horizontal grid consisted of wet cells; $15 \%$ of the three-dimensional grid consisted of wet cells hence leading to considerable computational efficiencies using the sparse coordinate system. The model used a linear free surface formulation.

The model was integrated using a mode-splitting scheme to separate the two-dimensional (2D) and three-dimensional (3D) modes. The time step for the 2D barotropic calculation was $3.75 \mathrm{~s}$; the time step for the 3D calculation was $60 \mathrm{~s}$. The model was stable according to the Courant-Friedrichs-Levy stability conditions in both 2D and 3D modes. Momentum advection was calculated using a simple second order, centred scheme. Tracer advection was calculated using the third-order Quadratic Upstream Interpolation for Convective Kinemat- 
ics with Estimated Streaming Term (QUICKEST) scheme (Leonard, 1979) along with the ULTIMATE limiting filter (Leonard, 1991).

Horizontal tracer diffusion was parameterized using a Laplacian scheme along geopotential surfaces; horizontal momentum mixing was parameterized using a Laplacian scheme along horizontal planes. Smagorinsky mixing coefficients (Smagorinsky, 1963) were used and are flow-dependent and varied horizontally as a function of the grid-size. Horizontal viscosity was set to $370 \mathrm{~m}^{2} \mathrm{~s}^{-1}$ in both directions. Vertical mixing was parameterized using the $\kappa-\varepsilon$ scheme of Burchard et al. (1998) with background viscosity and diffusivity values equal to $10^{-5} \mathrm{~m}^{2} \mathrm{~s}^{-1}$. Bottom friction used a combined linear and quadratic drag law with a minimum bottom drag coefficient of $3 \times 10^{-3}$, a background frictional velocity of $1 \times 10^{-4} \mathrm{~m} \mathrm{~s}^{-1}$, and a bottom roughness of $1.04 \times 10^{-2} \mathrm{~m}$.

Lateral open boundaries used the recently-developed Dirichlet boundary condition of Herzfeld and Andrewartha (2012) in which the 3D velocity fields were clamped to a specified value and the sea level is left unconstrained. A local flux adjustment, with a time scale of $2 \mathrm{~s}$, was applied to the depth-averaged velocity fields in order to prevent total volume drift over time. The flux adjustment was not applied at the northern boundary. Tracers were also specified on the "ghost" cells adjacent to the open boundaries and the tracer advection scheme used to solve the advection equation on the boundaries. The three-dimensional velocities, sea level (after removing the inverse barometer effect), and tracer concentrations (temperature and salinity) were specified daily from the $1 / 10^{\circ}$ Bluelink ReANalysis (BRAN, version 3, 1/1/1993-31/7/2012, Oke et al. (2013)) and OceanMAPS analysis (versions 2.02.2.1, 1/8/2012-31/12/2014; wp.csiro.au/bluelink). Filling in of dry cells in the Bluelink product fields, using the values of the nearest wet cells, was performed in order to have valid data for all wet cells in the high-resolution SHOC model. At the model solid boundaries, a free slip condition was applied with zero normal fluxes of momentum and tracers. Tidal forcing was provided by specifying sea level components at the seaward boundary using the Centre for Space Research 4.0 model (Eanes and Bettadpur, 1995).

Two major rivers lie in the model domain: the Derwent River and the Huon River (Fig- 
ure 1). River runoff was included by specifying the flow rate and temperature of freshwater input (zero salinity) every six hours at source boundaries located upriver from the marine environment, near locations of observed river flow rates. Relatively short observed records of river flow and temperature exist for the Derwent and Huon Rivers and these were reconstructed over the 1993-2014 period using reanalysed precipitation and air temperature over the river catchments and a lagged linear regression model (see Appendix A for details).

The model surface boundary forcing consisted of 6-hourly atmospheric fields provided by the National Centers for Environmental Prediction (NCEP) Climate Forecast System Reanalysis (CFSR, 1993-2010, Saha et al. (2010)) and Climate Forecast System Version 2 analysis (CSFv2, 2011-2014, Saha et al. (2014)). Surface wind stress was specified using a drag law with a piecewise linear drag coefficient (e.g., Large and Pond (1981)) and wind fields defined at $10 \mathrm{~m}$ above the sea surface. Air pressure at sea level was included through the force it exerts on the sea surface. Surface freshwater flux was calculated using bulk formulae, specified precipitation, and evaporation estimated through the latent heat of vaporization. Surface heat flux was calculated using an advanced bulk formula (Kondo, 1975) and using specified air temperature (at $10 \mathrm{~m}$ ), cloud cover, shortwave and longwave radiation at the surface, and the dew point temperature (estimated from specific humidity and air pressure, following Bolton (1980)). The shortwave radiation transmission and attenuation coefficients, controlling the degree to which shortwave radiation was excluded from the heat budget and the attenuation rate with depth, were set to 0.8 and 0.4 respectively and it was assumed any shortwave radiation reaching the bottom was absorbed into the sea bed. Sea surface albedo was calculated as a function of cloud cover and sun angle. The CFSR (CFSv2) fields were defined on a grid with a horizontal resolution of $0.3^{\circ}\left(0.2^{\circ}\right)$.

The model was initialized from the climatological mean state of 1/1/1993 from BRAN and spun up for three years using normal year forcing. Normal year forcing $\left(f_{\mathrm{NY}}\right)$ was calculated for each surface and boundary forcing variable $f$ following Large and Yeager $(2004): f_{\mathrm{NY}}=\bar{f}+f_{\mathrm{S}}+f_{\mathrm{NS}}$, where $\bar{f}$ is the time-mean of $f, f_{\mathrm{S}}$ is the seasonal cycle, and $f_{\mathrm{NS}}$ is the non-seasonal variability of $f$ filtered to remove signals with time scales longer than 
Table 1: Description of model runs.

\begin{tabular}{|c|c|c|c|}
\hline Name & Forcing & Length [years] & Details \\
\hline SPIN-R/T & Normal year & 3 & Spinup run with river inputs and tidal forcing \\
SPIN-R/T & Normal year & 3 & Spinup run with river inputs (no tidal forcing) \\
SPIN-R/T & Normal year & 3 & Spinup run with tidal forcing (no river inputs) \\
SPIN-R/T & Normal year & 3 & Spinup run (no river inputs or tidal forcing) \\
\hline R/T & $1993-2014$ & 22 & Hindcast run with river inputs and tidal forcing \\
R/NT & $1993-2014$ & 22 & Hindcast run with river inputs (no tidal forcing) \\
NR/T & $1993-2014$ & 22 & Hindcast run with tidal forcing (no river inputs) \\
NR/NT & $1993-2014$ & 22 & Hindcast run (no river inputs or tidal forcing) \\
\hline
\end{tabular}

two years. The model hindcast run was then initialized from the end of the spin-up run and forced over the 1993-2014 period by the interannually varying surface and boundary fields described above. The spinup and hindcast runs were performed for all combinations of with and without river inputs and tidal forcing (see Table 1 for a list of all model runs). Daily fields of sea surface height and three-dimensional fields of velocity, temperature, and salinity, were output every day. Hourly time series were output at specific points of interest (see Section 2.2).

\subsection{Observations and model evaluation methods}

Observations of ocean temperature, salinity, and currents off eastern Tasmania from a variety of measurement platforms were used to evaluate the model simulations. Model simulated variables for each station or gridded observation were extracted by interpolating the gridded model fields to the observation location.

In-situ measurements at point locations were obtained from a number of sites (see Figure $1 \mathrm{~b}$ for locations and Table 2 for details). Daily-mean measurements of near-bottom temperature were obtained from a number of temperature loggers distributed broadly over the continental shelf of Tasmania (Dr. Craig Mundy, University of Tasmania, pers comm). These loggers sit approximately $1 \mathrm{~m}$ off the sea floor in water depths ranging from $6 \mathrm{~m}$ to 
Table 2: Details of in-situ ocean observations used for model evaluation. The last column indicates the percentage of each time series that is non-missing data. In the case of the historical MITS data $\left(^{*}\right)$ the measurements were made at irregular intervals and therefore there are no "missing" measurements. See Figure $1 \mathrm{~b}$ for locations.

\begin{tabular}{|c|c|c|c|c|c|c|c|}
\hline Name & Latitude & Longitude & Depths $[\mathrm{m}]$ & Start & End & Rate & $\begin{array}{l}\text { Completenes\$ } \\
{[\%]}\end{array}$ \\
\hline \multicolumn{8}{|c|}{ Tide gauges $(\eta)$} \\
\hline Hobart & $42.8767^{\circ} \mathrm{S}$ & $147.3417^{\circ} \mathrm{E}$ & & $1 / 1 / 1985$ & $31 / 12 / 2012$ & Hourly & 81 \\
\hline Spring Bay & $42.5667^{\circ} \mathrm{S}$ & $147.9317^{\circ} \mathrm{E}$ & & $1 / 1 / 1985$ & $31 / 12 / 2012$ & Hourly & 96 \\
\hline \multicolumn{8}{|c|}{ Maria Island Time Series (MITS), historical $(T, S)$} \\
\hline MITS & $42.5918^{\circ} \mathrm{S}$ & $148.2335^{\circ} \mathrm{E}$ & $\begin{array}{l}0-50(10 \mathrm{~m} \\
\text { intervals })\end{array}$ & $15 / 10 / 1944$ & $21 / 5 / 2008$ & Approx. monthly & $100^{*}$ \\
\hline \multicolumn{8}{|c|}{ Maria Island Time Series (MITS), WQM $(T, S)$} \\
\hline MITS & $42.5918^{\circ} \mathrm{S}$ & $148.2335^{\circ} \mathrm{E}$ & 19,85 & $31 / 7 / 2008$ & $5 / 4 / 2014$ & 15 mins. & 87 \\
\hline \multicolumn{8}{|c|}{ Maria Island Time Series (MITS), ADCP $(u, v)$} \\
\hline MITS & $42.5918^{\circ} \mathrm{S}$ & $148.2335^{\circ} \mathrm{E}$ & $\begin{array}{l}14-82(4 \mathrm{~m} \\
\text { intervals })\end{array}$ & $21 / 7 / 2011$ & $17 / 4 / 2014$ & 15 mins. & $\begin{array}{l}90,92,94, \\
96,97,98, \\
98,98,98, \\
98,98,98, \\
98,98,98, \\
98,98,98\end{array}$ \\
\hline \multicolumn{8}{|c|}{ Storm Bay, Aquadopp $(u, v)$} \\
\hline Storm Bay & $43.3^{\circ} \mathrm{S}$ & $147.659^{\circ} \mathrm{E}$ & 20,65 & $5 / 4 / 2009$ & $4 / 5 / 2010$ & 10 mins. & $>99$ \\
\hline \multicolumn{8}{|c|}{ Near-bottom Temperature Loggers $(T)$} \\
\hline Eddystone Point & $40.9851^{\circ} \mathrm{S}$ & $148.3467^{\circ} \mathrm{E}$ & 11.0 & $28 / 5 / 2005$ & $29 / 1 / 2010$ & Daily & 100 \\
\hline Bicheno & $41.8716^{\circ} \mathrm{S}$ & $148.3110^{\circ} \mathrm{E}$ & 13.0 & $3 / 6 / 2005$ & $21 / 2 / 2013$ & Daily & 100 \\
\hline Swansea & $42.1239^{\circ} \mathrm{S}$ & $148.0925^{\circ} \mathrm{E}$ & 8.3 & $4 / 5 / 2005$ & $21 / 2 / 2012$ & Daily & 60 \\
\hline Coles Bay & $42.1342^{\circ} \mathrm{S}$ & $148.2962^{\circ} \mathrm{E}$ & 6.0 & $15 / 1 / 2007$ & $3 / 11 / 2011$ & Daily & 100 \\
\hline Hazards Beach & $42.1916^{\circ} \mathrm{S}$ & $148.2844^{\circ} \mathrm{E}$ & 6.5 & $4 / 5 / 2005$ & $21 / 2 / 2012$ & Daily & 100 \\
\hline Schouten Island & $42.2807^{\circ} \mathrm{S}$ & $148.2903^{\circ} \mathrm{E}$ & 12.0 & $15 / 1 / 2007$ & $21 / 2 / 2012$ & Daily & 100 \\
\hline Magistrates Point & $42.5860^{\circ} \mathrm{S}$ & $148.0506^{\circ} \mathrm{E}$ & 10.1 & $22 / 6 / 2004$ & $6 / 7 / 2012$ & Daily & 61 \\
\hline Cape Peron & $42.7432^{\circ} \mathrm{S}$ & $148.0125^{\circ} \mathrm{E}$ & 12.0 & $3 / 5 / 2005$ & $6 / 7 / 2012$ & Daily & 100 \\
\hline Iron Pot & $43.0530^{\circ} \mathrm{S}$ & $147.4167^{\circ} \mathrm{E}$ & 9.0 & $5 / 12 / 2006$ & $27 / 2 / 2013$ & Daily & 100 \\
\hline One Tree Point & $43.1087^{\circ} \mathrm{S}$ & $147.3866^{\circ} \mathrm{E}$ & 8.0 & $27 / 9 / 2004$ & $18 / 12 / 2012$ & Daily & 100 \\
\hline Wedge Island & $43.1273^{\circ} \mathrm{S}$ & $147.6753^{\circ} \mathrm{E}$ & 10.2 & $17 / 5 / 2005$ & $17 / 12 / 2012$ & Daily & 89 \\
\hline Tasman Island & $43.2324^{\circ} \mathrm{S}$ & $148.0067^{\circ} \mathrm{E}$ & 12.0 & $12 / 1 / 2006$ & $4 / 11 / 2012$ & Daily & 37 \\
\hline George III Reef & $43.5085^{\circ} \mathrm{S}$ & $146.9831^{\circ} \mathrm{E}$ & 10.2 & $27 / 5 / 2004$ & $18 / 12 / 2012$ & Daily & 85 \\
\hline Mouldies Hole & $43.5939^{\circ} \mathrm{S}$ & $146.9199^{\circ} \mathrm{E}$ & 6.0 & $25 / 2 / 2005$ & $19 / 3 / 2013$ & Daily & 81 \\
\hline
\end{tabular}


13 m. Hourly measurements of sea level at two tide gauges (Hobart and Spring Bay) were obtained from the Hawai'i Sea Level Center (http://uhslc.soest.hawaii.edu/); prior to analysis the tidal constituents were removed using the T_TIDE software package (Pawlowicz et al., 2002) and the residual averaged to daily values.

Measurements of temperature and salinity near Maria Island (Maria Island Time Series, MITS) at the surface and each $10 \mathrm{~m}$ down to $50 \mathrm{~m}$ depth, at an approximately monthly rate, were obtained from CSIRO Marine and Atmospheric Research for the 1993-2008 period. More recent MITS data include Water Quality Monitor (WQM) measurements of temperature and salinity at $19 \mathrm{~m}$ and $85 \mathrm{~m}$ depth and ADCP measurements of zonal and meridional currents throughout the water column at 15-minute intervals over 2011-2014 were obtained from the Integrated Marine Observing System (IMOS; www.imos.org.au). Measurements of zonal and meridional currents at $20 \mathrm{~m}$ and $65 \mathrm{~m}$ from a Aquadopp acoustic current meter moored in Storm Bay were also obtained from IMOS, covering approximately one year across 2009-2010. These current speed data have had their tidal components removed using a 39point Doodson X0 filter (Doodson, 1928) and were then averaged to daily means, rejecting any data not flagged as "good data" or "probably good data" by IMOS.

Sea surface temperatures were obtained daily for the entire simulation period (1993-2014) from the National Oceanic and Atmospheric Administration (NOAA) Optimum Interpolation (OI) Sea Surface Temperature (SST) V2 high resolution gridded $\left(1 / 4^{\circ} \times 1 / 4^{\circ}\right)$ dataset (Reynolds et al., 2007) which was derived from remotely-sensed SST by the satellite-borne Advanced Very High Resolution Radiometer (AVHRR) imager.

Evaluation methods used to compare the model simulations against the ocean observations are as follows. Time series of each variable $y$ were decomposed into a sum as follows: $y=\mu+y_{\mathrm{S}}+y^{\prime}$, where $\mu$ is the time-mean, $y_{\mathrm{S}}$ is the seasonal cycle, and $y^{\prime}$ is the residual (non-seasonal) variability. The seasonal cycle was estimated by harmonic regression including the annual and semi-annual cycles and was reported as the amplitude ( $A$; mean-to-peak range) and phase ( $\phi$; day-of-year for peak value). Both the total $(y)$ and residual $\left(y^{\prime}\right)$ time series were compared between the model and observations using the Willmott skill score ( $d$; 
Willmott (1981)) of the daily data as well as of monthly or annual averages in cases where the time series were long enough. The Willmott skill score is defined as

$$
d=1-\frac{\sum_{t=1}^{T}[\operatorname{obs}(t)-\bmod (t)]^{2}}{\sum_{t=1}^{T}[|\bmod (t)-\overline{\mathrm{obs}}|+|\operatorname{obs}(t)-\overline{\mathrm{obs}}|]^{2}}
$$

and is a measure of the agreement between an observed variable and model simulations and varies between 0 and 1 where 1 indicates perfect agreement and 0 indicates a range of possible disagreements.

\section{Model Evaluation}

Model performance was evaluated against coastal sea level (Section 3.1), the Maria Island Time Series (Sections 3.2 and 3.3), Storm Bay velocities (Sections 3.4), near-bottom temperature (Section 3.5), and gridded sea surface temperature (Section 3.6) observations. The R/NT run (see definition in Table 1) was used to evaluate model performance. A corresponding evaluation of BRAN against the same data can be found in the supplementary material and demonstrates that the present model is generally an improvement over BRAN in this context.

\subsection{Coastal sea level}

Coastal sea levels at Hobart and Spring Bay tide gauges are shown in Figure 2 (black lines). There was variability on a range of time scales from daily through to interannual (and longer). The model simulated sea levels captured the observed sea levels well (Figure 2, red lines). The observed and modeled amplitude of the annual cycle over the full 1985-2012 period were $4.64 \mathrm{~cm}(3.80 \mathrm{~cm})$ and $3.36 \mathrm{~cm}(2.04 \mathrm{~cm})$, respectively, at Hobart (Spring Bay), which was good agreement (Table $3, A_{\text {mod }}$ and $A_{\text {obs }}$ ). The phase timing of the seasonal cycle was also well captured, with the simulated peak sea level occurring within about one month of the observed peak sea level (Table $3, \phi_{0, \text { mod }}$ and $\phi_{0, \text { obs }}$ ). The variability was also well-represented, with skill scores $\sim 0.9$ between observed and modeled sea level for both the total and residual time series (Table $3, d$ and $d^{\prime}$ ); skill scores also indicated good agreement 

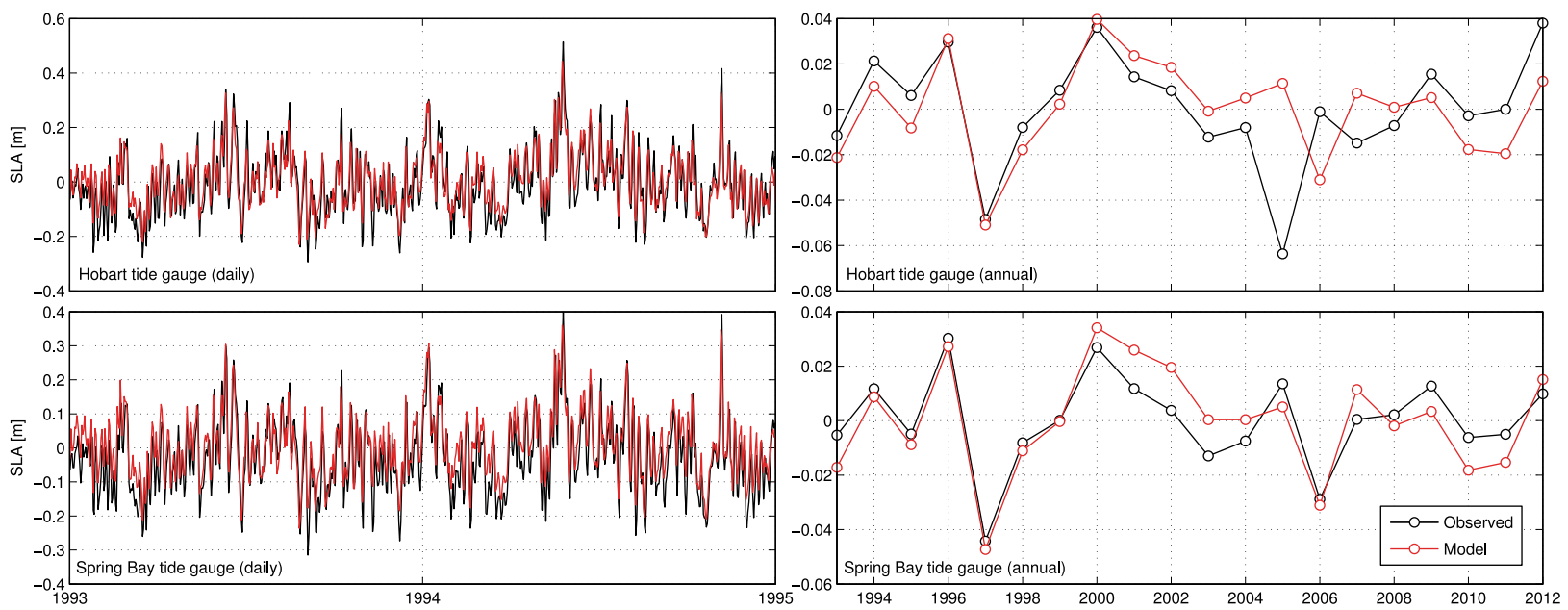

Figure 2: Coastal sea level time series. Shown are (left) daily averages and (right) annual anomalies of observed (black) and model simulated (red) sea levels at (upper) Hobart and (lower) Spring Bay tide gauges. The daily averages are only shown over a two-year subset for clarity.

Table 3: Evaluation of coastal sea levels. Shown are the observed and model simulated seasonal cycle amplitude (mean to peak in $\mathrm{cm} ; A$ ), seasonal cycle phase (day-of-year at which peak occurs; $\phi_{0}$ ) and skill scores for total $(d)$, residual $\left(d^{\prime}\right)$, and annual averaged $\left(d^{\text {an }}\right)$ sea level time series.

\begin{tabular}{|c|cc|ccc|}
\hline Tide gauge & $A_{\text {mod }}\left(A_{\text {obs }}\right)$ & $\phi_{0, \bmod }\left(\phi_{0, \text { obs }}\right)$ & $d$ & $d^{\prime}$ & $d^{\text {an }}$ \\
\hline Hobart & $3.80(4.64)$ & $178(202)$ & 0.89 & 0.88 & 0.73 \\
Spring Bay & $2.04(3.36)$ & $153(188)$ & 0.91 & 0.91 & 0.94 \\
\hline
\end{tabular}

for variability on longer timescales: for annual averaged sea levels skill scores were $0.73(0.94)$ for Hobart (Spring Bay; Table 3, $\left.d^{\text {an }}\right)$.

\subsection{Historical Maria Island Time Series: $T$ and $S$}

Observed temperature from MITS at the surface and selected sub-surface levels are shown in Figure 3 (upper panels, black lines) over 1993-2008. There was a strong seasonal cycle as well as variability on both shorter (monthly) and longer (interannual) time scales. The model simulated temperatures captured the observed time series well (Figure 3, upper panels, red lines). The mean temperature of the model simulation was generally within $\pm 0.1^{\circ} \mathrm{C}$ except in the upper $10 \mathrm{~m}$ where it was within $\pm 0.6^{\circ} \mathrm{C}$, with the model consistently warmer than 

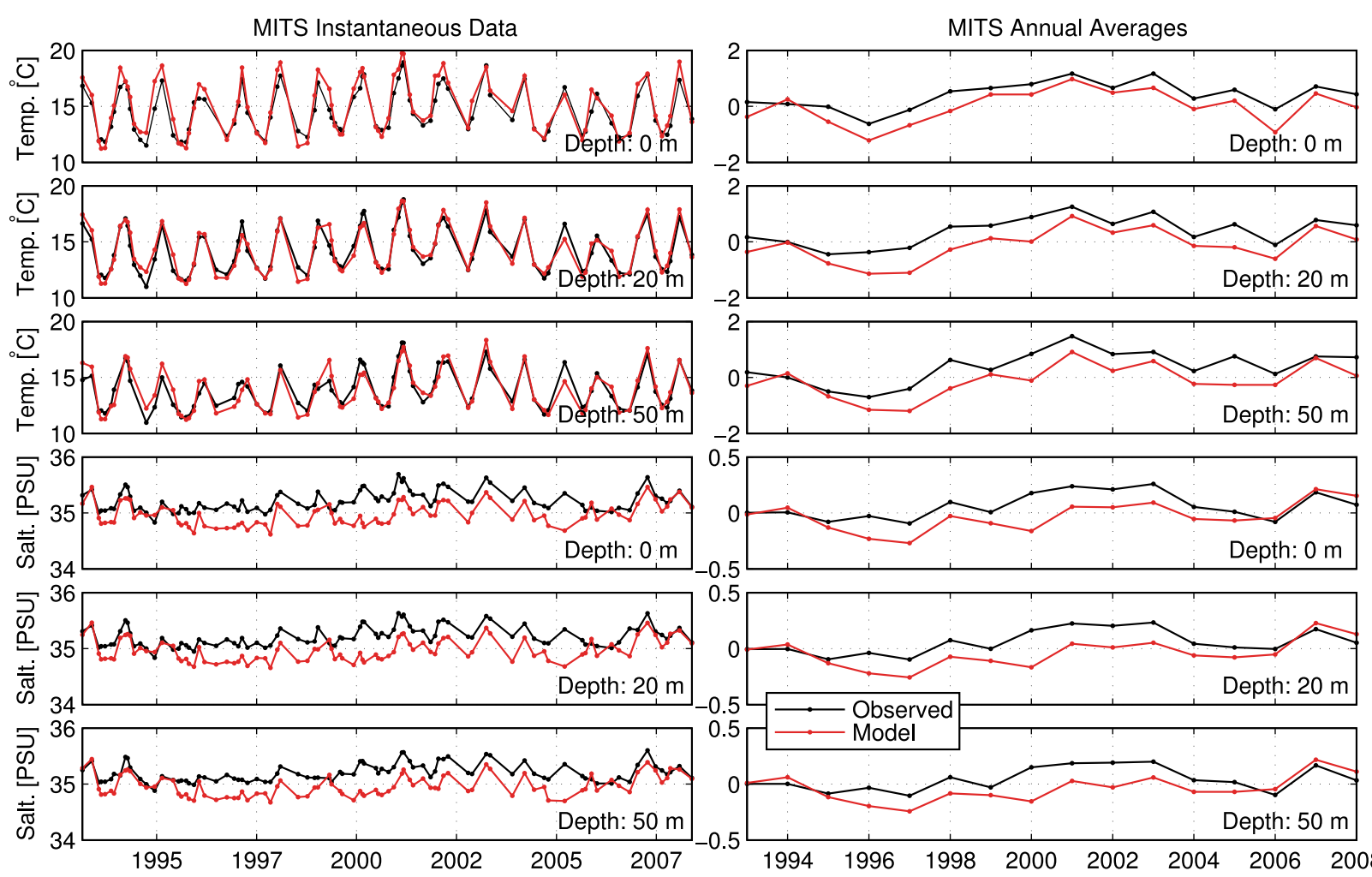

Figure 3: Historical temperature and salinity from the Maria Island Time Series (MITS). Shown are (left) instantaneous measurements and (right) annual averages of observed (black) and model simulated (red) temperature (upper panels) and salinity (lower panels). Time series are shown only at $0 \mathrm{~m}, 20 \mathrm{~m}$, and $50 \mathrm{~m}$ depths (10 m, $30 \mathrm{~m}$, and $40 \mathrm{~m}$ are excluded) for simplicity. 
the observations (Table $4, \mu_{\text {mod }}$ and $\mu_{\text {obs }}$ ). The amplitude of the annual cycle decreased through the water column in both the observations and the model, although it was over predicted in the model by $\sim 0.5^{\circ} \mathrm{C}$ (Table $4, A_{\text {mod }}$ and $A_{\text {obs }}$ ), and the timing of the seasonal peak value was generally within one month of the observations (Table $4, \phi_{0, \text { mod }}$ and $\phi_{0, \text { obs }}$ ).

The variability was also well-represented, with skill scores above 0.95 throughout the water column for the total time series (Table $4, d$ ); skill scores also indicated good agreement for non-seasonal variability $\left(d^{\prime}>0.75\right)$ and interannual variability $\left(d^{\text {an }} \geq 0.78\right)$.

Observed salinity from MITS at the surface and selected sub-surface levels are shown in Figure 3 (lower panels, black lines). In contrast to MITS temperature, there was a weak seasonal cycle as well as variability on both shorter (monthly) and longer (interannual) time scales. The model simulated salinity captured the seasonal cycle well (Figure 3, lower panels, red lines) but there was a bias in the mean salinity, with the model being too fresh by $\sim 0.25$ PSU (Table $4, \mu_{\text {mod }}$ and $\mu_{\text {obs }}$ ). The amplitude of the annual cycle decreased slightly through the water column in both the observations and the model, although it was underpredicted in the model by 0.06-0.09 PSU (Table $4, A_{\text {mod }}$ and $A_{\text {obs }}$ ), and the timing of the seasonal peak value was always within one month of the observations (Table $4, \phi_{0, \text { mod }}$ and $\phi_{0, \text { obs }}$ ). The variability of salinity was well-represented, although not as well as for temperature, with skill scores above 0.55 throughout the water column for the total time series (Table $4, d$ ); skill scores indicated better agreement for non-seasonal variability $\left(d^{\prime}>0.60\right)$ and interannual variability $\left(d^{\text {an }} \geq 0.65\right)$. The bias in the mean and under-prediction of the seasonal range for salinity were features also present in BRAN (see supplementary material) and were likely communicated to the ETAS model through the boundary forcing.

\subsection{Recent Maria Island Time Series: T, S, u and $v$}

Observed currents at Maria Island over 2011-2014 indicated a mean northward flow generally in the range of $4-6 \mathrm{~cm} / \mathrm{s}$ and a weaker eastward component of $1-3 \mathrm{~cm} / \mathrm{s}$, throughout the water column (Table $5, \mu_{\mathrm{obs}}$ ). The seasonal cycle in meridional flow had an amplitude of $2.5-5 \mathrm{~cm} / \mathrm{s}$ throughout the water column, always less than the mean flow indicating a mean northward flow at all times of year, and the seasonal cycle in zonal flow had a weaker 
Table 4: Evaluation of temperature and salinity at Maria Island historical time series. Shown are the observed and model simulated mean (in ${ }^{\circ} \mathrm{C}$ for $T$ and PSU for $S ; \mu$ ), seasonal cycle amplitude (mean to peak, same units; $A$ ), seasonal cycle phase (month-of-year at which peak occurs; $\phi_{0}$ ) and skill scores for total $(d)$, residual $\left(d^{\prime}\right)$, and annual averaged $\left(d^{\text {an }}\right)$ time series of temperature $T$ and salinity $S$.

\begin{tabular}{|c|c|cc|ccc|}
\hline Variable $(\mathrm{Depth})$ & $\mu_{\text {mod }}\left(\mu_{\mathrm{obs}}\right)$ & $A_{\text {mod }}\left(A_{\mathrm{obs}}\right)$ & $\phi_{0, \text { mod }}\left(\phi_{0, \mathrm{obs}}\right)$ & $d$ & $d^{\prime}$ & $d^{\text {an }}$ \\
\hline$T(0 \mathrm{~m})$ & $15.03(14.55)$ & $3.03(2.42)$ & $2(1)$ & 0.96 & 0.80 & 0.83 \\
$T(10 \mathrm{~m})$ & $14.74(14.33)$ & $2.85(2.36)$ & $2(3)$ & 0.97 & 0.82 & 0.86 \\
$T(20 \mathrm{~m})$ & $14.31(14.22)$ & $2.61(2.23)$ & $3(3)$ & 0.98 & 0.76 & 0.78 \\
$T(30 \mathrm{~m})$ & $14.10(14.18)$ & $2.46(2.18)$ & $3(3)$ & 0.97 & 0.76 & 0.79 \\
$T(40 \mathrm{~m})$ & $13.96(14.01)$ & $2.38(2.05)$ & $3(3)$ & 0.96 & 0.76 & 0.79 \\
$T(50 \mathrm{~m})$ & $13.89(13.90)$ & $2.29(1.89)$ & $2(6)$ & 0.96 & 0.75 & 0.78 \\
\hline$S(0 \mathrm{~m})$ & $34.98(35.22)$ & $0.14(0.20)$ & $3(3)$ & 0.59 & 0.64 & 0.68 \\
$S(10 \mathrm{~m})$ & $34.98(35.22)$ & $0.13(0.22)$ & $3(3)$ & 0.59 & 0.66 & 0.70 \\
$S(20 \mathrm{~m})$ & $34.97(35.22)$ & $0.13(0.20)$ & $3(3)$ & 0.57 & 0.62 & 0.65 \\
$S(30 \mathrm{~m})$ & $34.97(35.21)$ & $0.13(0.21)$ & $3(3)$ & 0.57 & 0.63 & 0.66 \\
$S(40 \mathrm{~m})$ & $34.97(35.21)$ & $0.13(0.20)$ & $3(4)$ & 0.57 & 0.63 & 0.66 \\
$S(50 \mathrm{~m})$ & $34.97(35.20)$ & $0.12(0.19)$ & $3(4)$ & 0.55 & 0.60 & 0.65 \\
\hline
\end{tabular}


amplitude of 1-2 cm/s (Table $5, A_{\mathrm{obs}}$ ). The timing of the seasonal cycle was such that peak (northward) flow was reached on day 205-235 of the year (i.e., July-August; Table 5, $\phi_{0, \text { obs }}$ ) which was consistent with the Zeehan Current, and which is known to peak in strength in austral winter; peak eastward flow also generally occurred around this time, although earlier in the year above $50 \mathrm{~m}$ depth (Table $5, A_{\text {obs }}$ ). The model reproduced the mean northward direction of flow and the timing of the seasonal cycle but underestimated both (Table $5, \mu_{\text {mod }}$ and $\left.A_{\text {mod }}\right)$. The model simulated mean westward flow in the upper $50 \mathrm{~m}$ and mean eastward flow below that depth as well as a general underestimate in the magnitude of the mean and seasonal cycle. The variability of the total time series was generally well-represented, with skill scores $\sim 0.6$ for $v$ and $0.37-0.57$ for $u$ (Table $4, d$ ). Skill scores of the non-seasonal variability $\left(d^{\prime}\right)$ were similar to those for the total time series for $v$ and slightly lower for $u$. Skill scores for monthly averaged data $\left(d^{\text {mth }}\right)$ were generally good for $v(0.62-0.80)$ and moderate for $u(0.39-0.70)$. It is perhaps not surprising that the model simulates $v$ better than $u$ as it would be expected that the cross-shore current (closely approximated by $u$ ) so close to land would be much more difficult to simulate accurately, given the discretization and uncertainties in the coastline and bathymetry, than the along-shore current (closely approximated by $v$ ).

Observations of temperature and salinity at Maria Island from the WQM records and the model skill at reproducing them (Table 5) were consistent with the historical records (Table 4) and so we do not describe these results in detail here other than to reiterate that the model performs well at simulating temperature and less well at simulating salinity.

\subsection{Storm Bay currents}

Observed currents in Storm Bay over 2009-2010 indicated a mean northeastward flow of $(u, v)=(1.21,1.96) \mathrm{cm} / \mathrm{s}$ at $20 \mathrm{~m}$ and $(1.65,1.42) \mathrm{cm} / \mathrm{s}$ at $65 \mathrm{~m}$ (Table $\left.6, \mu_{\mathrm{obs}}\right)$. The model reproduced the mean northeastward flow although stronger in the eastward direction than the observations: $(2.92,1.84) \mathrm{cm} / \mathrm{s}$ at $20 \mathrm{~m}$ and $(2.43,1.27) \mathrm{cm} / \mathrm{s}$ at $65 \mathrm{~m}$. This shows the dominance, in both the model and observations, of the northeastward Zeehan Current in Storm Bay. The variability of the total time series was generally well-represented, with 
Table 5: Evaluation of WQM and ADCP measurements at Maria Island time series. Shown are the observed and model simulated mean (in ${ }^{\circ} \mathrm{C}$ for $T$, PSU for $S$, and $\mathrm{cm} / \mathrm{s}$ for $u$ and $v ; \mu$ ), seasonal cycle amplitude (mean to peak, same units; $A$ ), seasonal cycle phase (day-of-year at which peak occurs; $\phi_{0}$ ) and skill scores for total $(d)$, residual $\left(d^{\prime}\right)$, and monthly-averaged $\left(d^{\mathrm{mth}}\right)$ time series of zonal current $u$, meridional current $v$, temperature $T$ and salinity $S$.

\begin{tabular}{|c|c|c|c|c|c|c|}
\hline Variable (Depth) & $\mu_{\bmod }\left(\mu_{\mathrm{obs}}\right)$ & $A_{\text {mod }}\left(A_{\text {obs }}\right)$ & $\phi_{0, \bmod }\left(\phi_{0, \mathrm{obs}}\right)$ & $d$ & $d^{\prime}$ & $d^{\mathrm{mth}}$ \\
\hline$u(14 \mathrm{~m})$ & $-0.57(2.81)$ & $0.28(1.86)$ & $172(176)$ & 0.41 & 0.31 & 0.43 \\
\hline$u(18 \mathrm{~m})$ & $-0.57(2.23)$ & $0.28(1.26)$ & $172(183)$ & 0.42 & 0.34 & 0.48 \\
\hline$u(22 \mathrm{~m})$ & $-0.51(2.00)$ & $0.18(1.37)$ & $172(185)$ & 0.40 & 0.32 & 0.50 \\
\hline$u(26 \mathrm{~m})$ & $-0.37(1.77)$ & $0.11(1.27)$ & $182(186)$ & 0.39 & 0.31 & 0.50 \\
\hline$u(30 \mathrm{~m})$ & $-0.22(1.53)$ & $0.07(1.17)$ & $203(189)$ & 0.38 & 0.31 & 0.52 \\
\hline$u(34 \mathrm{~m})$ & $-0.22(1.29)$ & $0.07(1.02)$ & $203(194)$ & 0.38 & 0.32 & 0.53 \\
\hline$u(38 \mathrm{~m})$ & $-0.11(1.13)$ & $0.05(0.99)$ & $219(198)$ & 0.37 & 0.33 & 0.55 \\
\hline$u(42 \mathrm{~m})$ & $-0.11(1.04)$ & $0.05(0.99)$ & $219(203)$ & 0.38 & 0.34 & 0.57 \\
\hline$u(46 \mathrm{~m})$ & $0.01(1.02)$ & $0.08(1.07)$ & $216(207)$ & 0.38 & 0.36 & 0.60 \\
\hline$u(50 \mathrm{~m})$ & $0.01(1.04)$ & $0.08(1.09)$ & $216(212)$ & 0.39 & 0.37 & 0.61 \\
\hline$u(54 \mathrm{~m})$ & $0.18(1.10)$ & $0.19(1.13)$ & $202(217)$ & 0.41 & 0.39 & 0.60 \\
\hline$u(58 \mathrm{~m})$ & $0.18(1.20)$ & $0.19(1.16)$ & $202(221)$ & 0.42 & 0.40 & 0.59 \\
\hline$u(62 \mathrm{~m})$ & $0.34(1.35)$ & $0.58(1.19)$ & $201(223)$ & 0.48 & 0.45 & 0.59 \\
\hline$u(66 \mathrm{~m})$ & $0.34(1.54)$ & $0.58(1.22)$ & $201(222)$ & 0.50 & 0.46 & 0.61 \\
\hline$u(70 \mathrm{~m})$ & $0.34(1.76)$ & $0.58(1.20)$ & $201(220)$ & 0.51 & 0.47 & 0.61 \\
\hline$u(74 \mathrm{~m})$ & $0.21(2.01)$ & $1.17(1.18)$ & $206(216)$ & 0.56 & 0.53 & 0.70 \\
\hline$u(78 \mathrm{~m})$ & $0.21(2.17)$ & $1.17(1.17)$ & $206(210)$ & 0.57 & 0.54 & 0.68 \\
\hline$u(82 \mathrm{~m})$ & $0.21(2.08)$ & $1.17(1.31)$ & $206(209)$ & 0.58 & 0.56 & 0.68 \\
\hline$v(14 \mathrm{~m})$ & $1.07(4.20)$ & $1.65(2.94)$ & $203(230)$ & 0.58 & 0.58 & 0.61 \\
\hline$v(18 \mathrm{~m})$ & $1.07(4.49)$ & $1.65(2.67)$ & $203(234)$ & 0.57 & 0.58 & 0.60 \\
\hline$v(22 \mathrm{~m})$ & $0.91(5.08)$ & $1.71(3.04)$ & $201(217)$ & 0.58 & 0.59 & 0.67 \\
\hline$v(26 \mathrm{~m})$ & $0.84(5.40)$ & $1.75(3.23)$ & $200(213)$ & 0.58 & 0.59 & 0.68 \\
\hline$v(30 \mathrm{~m})$ & $0.87(5.39)$ & $1.81(3.06)$ & $200(212)$ & 0.58 & 0.59 & 0.70 \\
\hline$v(34 \mathrm{~m})$ & $0.87(5.33)$ & $1.81(2.76)$ & $200(215)$ & 0.58 & 0.59 & 0.68 \\
\hline$v(38 \mathrm{~m})$ & $0.96(5.32)$ & $1.89(2.56)$ & $199(214)$ & 0.59 & 0.59 & 0.66 \\
\hline$v(42 \mathrm{~m})$ & $0.96(5.32)$ & $1.89(2.43)$ & $199(214)$ & 0.59 & 0.60 & 0.69 \\
\hline$v(46 \mathrm{~m})$ & $1.09(5.39)$ & $2.08(2.52)$ & $198(212)$ & 0.59 & 0.60 & 0.72 \\
\hline$v(50 \mathrm{~m})$ & $1.09(5.45)$ & $2.08(2.71)$ & $198(209)$ & 0.59 & 0.60 & 0.71 \\
\hline$v(54 \mathrm{~m})$ & $1.23(5.47)$ & $2.50(2.96)$ & $197(208)$ & 0.60 & 0.60 & 0.73 \\
\hline$v(58 \mathrm{~m})$ & $1.23(5.44)$ & $2.50(3.26)$ & $197(207)$ & 0.61 & 0.60 & 0.73 \\
\hline$v(62 \mathrm{~m})$ & $1.16(5.34)$ & $3.19(3.56)$ & 199 (206) & 0.62 & 0.61 & 0.76 \\
\hline$v(66 \mathrm{~m})$ & $1.16(5.18)$ & $3.19(3.88)$ & $199(205)$ & 0.62 & 0.61 & 0.77 \\
\hline$v(70 \mathrm{~m})$ & $1.16(4.89)$ & $3.19(4.20)$ & $199(205)$ & 0.63 & 0.62 & 0.77 \\
\hline$v(74 \mathrm{~m})$ & $0.74(4.44)$ & $2.98(4.50)$ & $200(206)$ & 0.60 & 0.57 & 0.77 \\
\hline$v(78 \mathrm{~m})$ & $0.74(3.87)$ & $2.98(4.71)$ & $200(207)$ & 0.62 & 0.58 & 0.78 \\
\hline$v(82 \mathrm{~m})$ & $0.74(3.21)$ & $2.98(4.54)$ & $200(208)$ & 0.64 & 0.61 & 0.80 \\
\hline$T(19 \mathrm{~m})$ & $14.63(14.48)$ & $2.61(2.58)$ & $62(64)$ & 0.98 & 0.75 & 0.82 \\
\hline$T(85 \mathrm{~m})$ & $13.73(13.61)$ & $1.99(1.62)$ & $81(p 3)$ & 0.94 & 0.73 & 0.78 \\
\hline$S(19 \mathrm{~m})$ & $35.16(35.27)$ & $0.12(0.12)$ & $88(97)$ & 0.64 & 0.50 & 0.50 \\
\hline$S(85 \mathrm{~m})$ & $35.15(35.24)$ & $0.11(0.07)$ & $94(126)$ & 0.58 & 0.45 & 0.44 \\
\hline
\end{tabular}


Table 6: Evaluation of Aquadopp velocity measurements in Storm Bay. Shown are the observed and model simulated mean (in $\mathrm{cm} / \mathrm{s} ; \mu)$ and skill scores for total $(d)$, residual $\left(d^{\prime}\right)$, and monthly-averaged $\left(d^{\mathrm{mth}}\right)$ time series of zonal current $u$ and meridional current $v$.

\begin{tabular}{|c|c|ccc|}
\hline Variable $($ Depth $)$ & $\mu_{\text {mod }}\left(\mu_{\text {obs }}\right)$ & $d$ & $d^{\prime}$ & $d^{\text {mth }}$ \\
\hline$u(20 \mathrm{~m})$ & $2.92(1.21)$ & 0.55 & 0.57 & 0.58 \\
$u(65 \mathrm{~m})$ & $2.43(1.65)$ & 0.59 & 0.60 & 0.62 \\
\hline$v(20 \mathrm{~m})$ & $1.84(1.96)$ & 0.44 & 0.42 & 0.41 \\
$v(65 \mathrm{~m})$ & $1.27(1.42)$ & 0.46 & 0.45 & 0.38 \\
\hline
\end{tabular}

skill scores $0.55-0.59$ for $u$ and $0.44-0.46$ for $v$ (Table $6, d$ ). Skill scores of the non-seasonal variability $\left(d^{\prime}\right)$ and the monthly averaged data $\left(d^{\text {mth }}\right)$ were similar to those for the total time series for both $u$ and $v$. The seasonal cycle was not calculated as the time series length (approx. one year) was too short to obtain a robust estimate.

\subsection{Near-bottom temperature}

Observed temperature from near-bottom temperature loggers across the domain are shown in Figure 4 (black lines). There was a strong seasonal cycle at all stations which the model captured well (4, red lines), with the notable exceptions of Swansea, Wedge Island, and George III Reef (see also Table $7, A_{\text {mod }}$ and $A_{\text {obs }}$ ). The mean temperature was also well-represented, with no consistent bias across all stations (Table $7, \mu_{\text {mod }}$ and $\mu_{\text {obs }}$ ). The variability was also well-represented, with skill scores above 0.90 for the total time series (Table $7, d$ ), except at George III reef where $d=0.68$. Non-seasonal variability showed good agreement ( $d^{\prime}$ in the range $\left.0.59-0.84\right)$ and monthly averages showed even better agreement ( $d^{\text {mth }}$ in the range $\left.0.69-0.87\right)$.

\subsection{Sea surface temperature}

Observed mean sea surface temperatures showed strong along-shore and cross-shore gradients in SST (Figure 5a). SSTs increased from $\sim 13^{\circ} \mathrm{C}$ in the southwest to nearly $\sim 16^{\circ} \mathrm{C}$ in the northeast. In addition, there was a positive SST gradient in the offshore direction across 


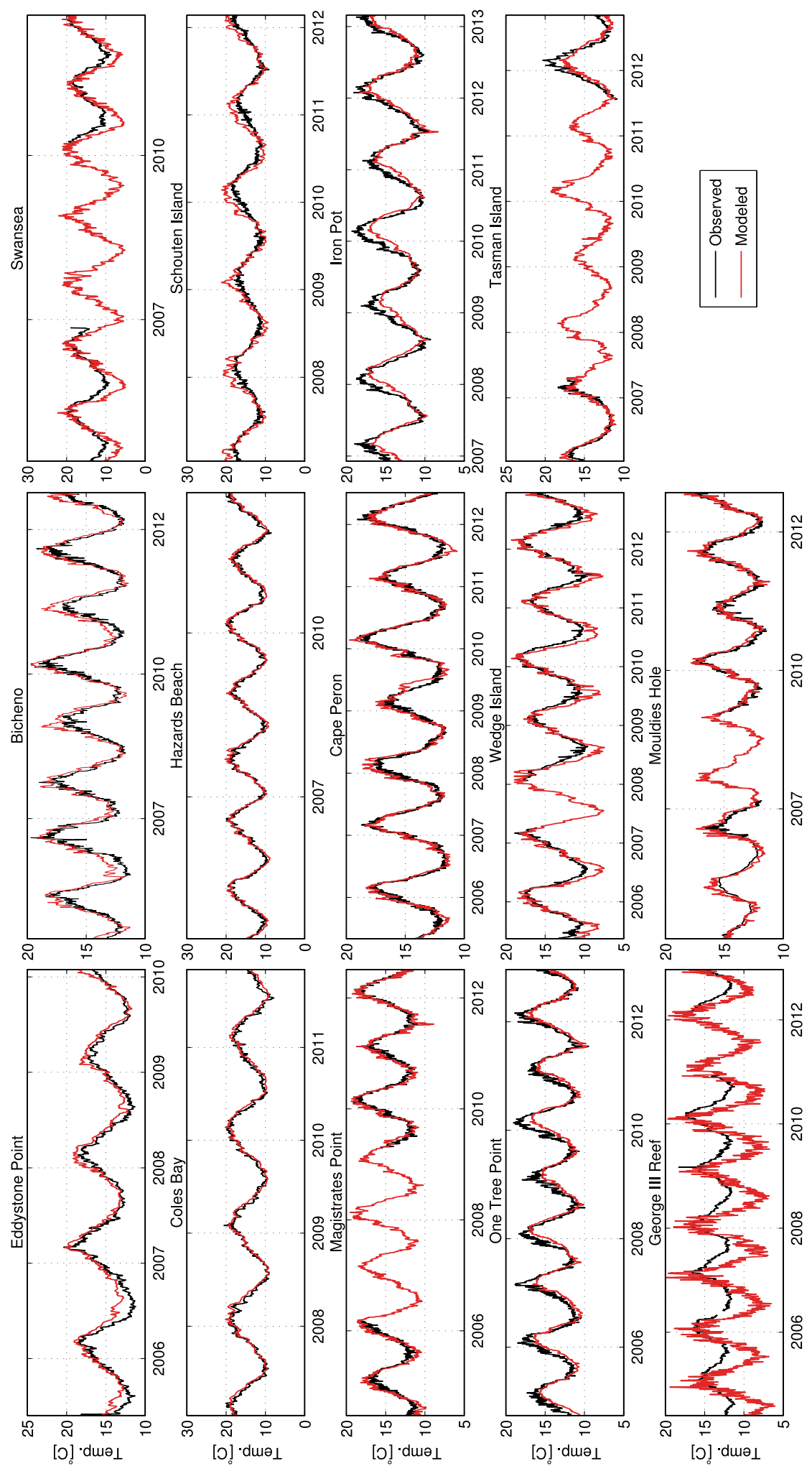

Figure 4: Temperature time series from near-bottom temperature loggers across the eastern Tasmania continental shelf. Shown are daily measurements of observed (black) and model simulated (red) near-bottom temperatures. 
Table 7: Evaluation of near-bottom temperature logger time series. Shown are the observed and model simulated mean (in ${ }^{\circ} \mathrm{C} ; \mu$ ), seasonal cycle amplitude (mean to peak, same units; $A$ ), seasonal cycle phase (day-of-year at which peak occurs; $\left.\phi_{0}\right)$ and skill scores for total $(d)$, residual $\left(d^{\prime}\right)$, and monthly-averaged $\left(d^{\text {mth }}\right)$ time series at each station.

\begin{tabular}{|c|c|cc|ccc|}
\hline Site & $\mu_{\text {mod }}\left(\mu_{\text {obs }}\right)$ & $A_{\text {mod }}\left(A_{\text {obs }}\right)$ & $\phi_{0, \text { mod }}\left(\phi_{0, \text { obs }}\right)$ & $d$ & $d^{\prime}$ & $d^{\text {mth }}$ \\
\hline Eddystone Point & $15.25(14.54)$ & $2.99(2.82)$ & $60(64)$ & 0.94 & 0.67 & 0.69 \\
Bicheno & $14.95(14.37)$ & $3.05(2.64)$ & $59(67)$ & 0.96 & 0.72 & 0.76 \\
Swansea & $12.71(14.47)$ & $6.30(4.33)$ & $28(47)$ & 0.90 & 0.74 & 0.81 \\
Coles Bay & $14.29(14.17)$ & $4.57(4.22)$ & $46(44)$ & 0.99 & 0.77 & 0.77 \\
Hazards Beach & $14.33(14.37)$ & $4.56(4.14)$ & $45(42)$ & 0.99 & 0.84 & 0.85 \\
Schouten Island & $14.90(14.34)$ & $4.70(3.02)$ & $34(60)$ & 0.92 & 0.66 & 0.72 \\
Magistrates Point & $14.36(14.30)$ & $3.36(2.88)$ & $51(59)$ & 0.98 & 0.83 & 0.84 \\
Cape Peron & $14.39(14.25)$ & $2.93(2.78)$ & $52(60)$ & 0.98 & 0.83 & 0.87 \\
Iron Pot & $13.53(13.99)$ & $2.74(3.48)$ & $67(50)$ & 0.95 & 0.70 & 0.73 \\
One Tree Point & $13.36(13.98)$ & $2.53(2.88)$ & $70(56)$ & 0.94 & 0.77 & 0.81 \\
Wedge Island & $13.01(13.70)$ & $4.49(3.41)$ & $44(55)$ & 0.96 & 0.84 & 0.87 \\
Tasman Island & $14.19(14.27)$ & $2.53(2.92)$ & $52(57)$ & 0.96 & 0.77 & 0.77 \\
George III Reef & $11.83(13.62)$ & $3.82(2.12)$ & $33(53)$ & 0.68 & 0.59 & 0.75 \\
Mouldies Hole & $14.01(13.87)$ & $1.96(1.91)$ & $53(54)$ & 0.97 & 0.81 & 0.85 \\
\hline
\end{tabular}

the shelf in the central and northern regions, indicative of the inshore influence of the northward Zeehan Current and offshore influence of the southward EAC Extension. The model simulated SST showed a similar pattern except that the cross-shelf gradient was weaker in the north and stronger in the south (Figure 5b). This is reflected in a positive SST bias $\left(\leq 0.5^{\circ} \mathrm{C}\right)$ in the near-shore regions (Figure $\left.5 \mathrm{c}\right)$. There is also a cold bias of up to $1.5^{\circ} \mathrm{C}$ in the Derwent and Huon estuaries, which may be due to the presence of river flow and/or the inaccuracy of remotely-sensed measurements of SST so close to the coast.

The observed SST seasonal cycle amplitude increased from $\sim 2^{\circ} \mathrm{C}$ in the south to $\sim 3^{\circ} \mathrm{C}$ in the north (Figure 5d). The model simulated seasonal cycle had a similar amplitude (Figure 5e), with an overestimate of up to $0.5^{\circ} \mathrm{C}$ in some regions of the shelf (near the coast) and up to $1.5^{\circ} \mathrm{C}$ in shallow, sheltered bays (Great Oyster Bay and the Derwent and Huon estuary mouths; Figure 5f). The timing of the seasonal cycle peak occurred between the 30th and 60th days of the year in both the the observations (Figure $5 \mathrm{~g}$ ) and the model simulations (Figure 5h). However, the model had a bias with the peak occurring earlier in the year 
closer to the coast while the observations showed the peak occurring later in the year closer to the coast (Figure 5i). The model is nevertheless consistent with in-situ observations of the seasonal cycle timing which show that the seasonal peak occurs about one month earlier in inshore regions than offshore (Harris et al., 1987), and so the apparent bias in Figure 5 may have been due to the inaccuracy of remotely-sensed measurements of SST near the coast.

The variability of SST was also well represented by the model (Figure 6). The skill score $d$ for total SST variability was above 0.95 over most of the domain, dropping as low as 0.8 in a few isolated near-shore locations (Figure 6a). The skill score for daily non-seasonal variability $d^{\prime}$ showed good agreement over the entire domain $\left(d^{\prime} \geq 0.7\right)$ with greatest skill along the offshore and southern boundaries and lowest skill very close to the coast (Figure 6b). Monthly-means and annual-means of non-seasonal variability showed better agreement with skill scores above 0.85 and 0.90 respectively, again with lowest skill very close to the coast.

\section{Results 1: Mean state and seasonal cycle}

In this section we present the mean state (Section 4.1) and seasonal cycle (Section 4.2) of the simulated eastern Tasmanian continental shelf marine climate.

\subsection{Mean state}

The mean state of the R/NT run over 1993-2014 indicated a strong north-south gradient in temperature, salinity, and circulation (Figure 7). Surface temperatures over the continental shelf ranged from $13.0^{\circ} \mathrm{C}$ in the south to $15.9^{\circ} \mathrm{C}$ in the north; coolest temperatures $\left(11-13^{\circ} \mathrm{C}\right)$ were found in the Derwent and Huon estuaries (Figure 7a, colours). Surface salinity showed a similar pattern increasing from 34.86 PSU in the south to $35.25 \mathrm{PSU}$ in the north, with salinity dropping much lower in the estuaries due to freshwater runoff (Figure 7b, colours). Surface circulation showed the dominance of northeastward flow south and east of the Tasman Peninsula (the Zeehan Current) and predominantly southward flow north of $42.5^{\circ} \mathrm{S}$ (the EAC Extension; Figure 7a,b, arrows). These main flows meet and turn offshore over the latitude range $42.5-43^{\circ} \mathrm{S}$. The northward flow of the Zeehan Current noticeably 
(a) Observed (NOAAOI) mean SST [deg. C]



(b) Modeled mean SST [deg. C]


(c) Difference [deg. C]
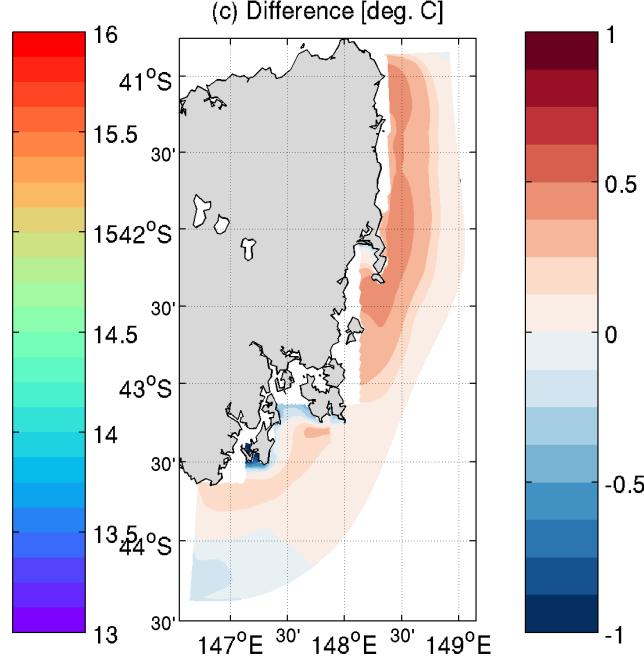

(d) Observed (NOAAOI) SST seas. cyc. amp. [deg. C] (e) Modeled SST seas. cyc. amp. [deg. C]
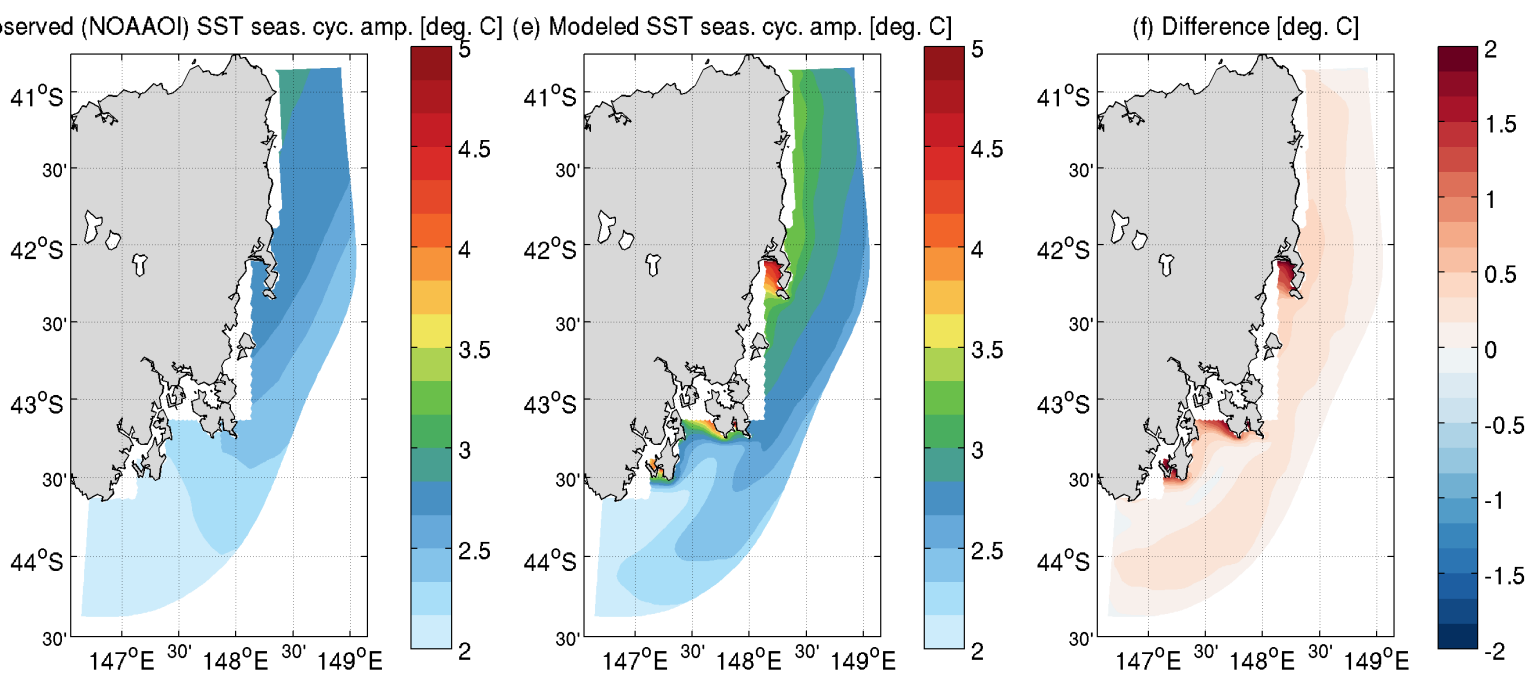

(g) Observed (NOAAOI) SST seas. cyc. phase [days] (h) Modeled SST seas. cyc. phase [days]


Figure 5: Mean and seasonal cycle of sea surface temperature. The mean SST is shown for (a) the NOAA OI product (observations) and for (b) the model simulation. The difference (model minus observation) is shown in panel (c). The amplitude and timing (day-of-year of the peak) of the seasonal cycle is shown for ( $\mathrm{d}$ and $\mathrm{g}$ ) the observations, (e and h) the model simulation, and ( $\mathrm{f}$ and i) their difference. 

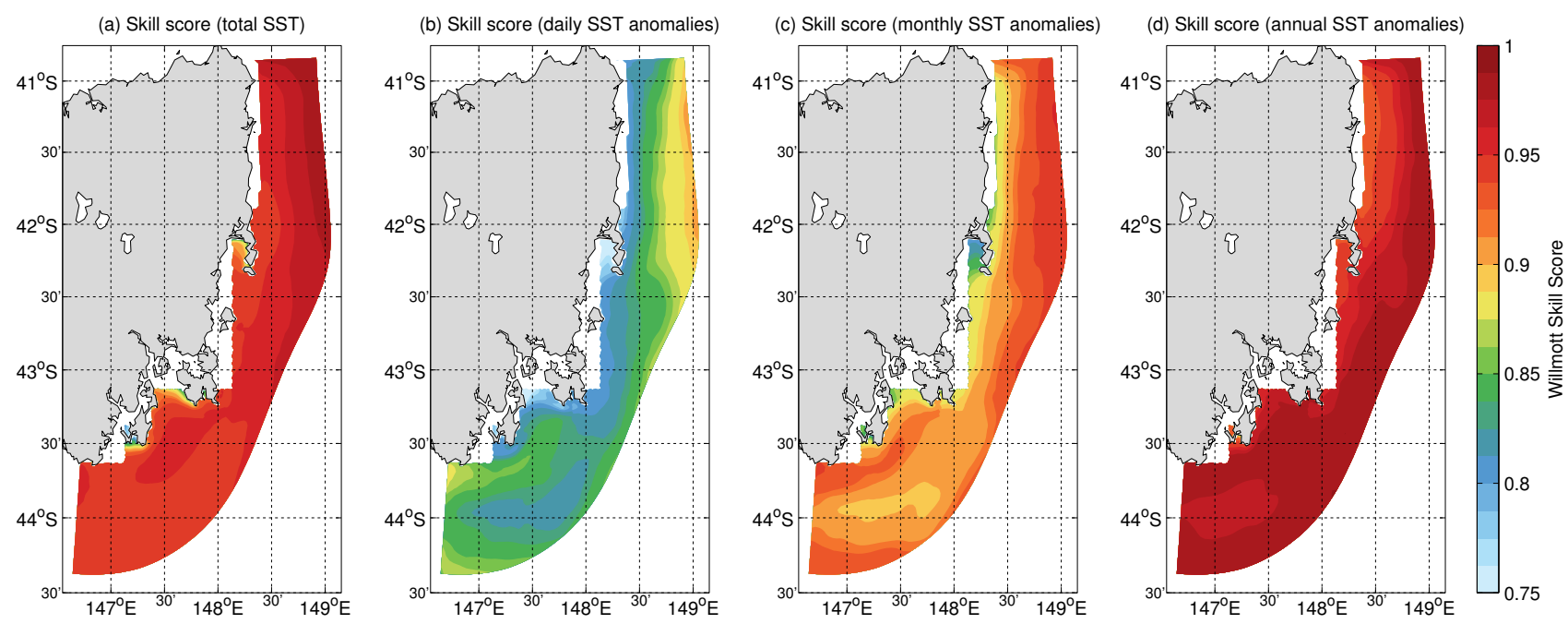

Figure 6: Model skill for sea surface temperatures. Shown is the Wilmott skill score between NOAA OI and model simulated SSTs for (a) the total time series $(d)$, (b) the daily, (c) monthly, and (d) residual time series $\left(d^{\prime}, d^{\mathrm{mth}}, d^{\mathrm{an}}\right)$.

intensified southeast of the Tasman Peninsula $\left(\sim 43.25^{\circ} \mathrm{S}\right)$ due to the narrowing of the continental shelf there. It should be noted also that in the northernmost portion of the domain (north of $42.5^{\circ} \mathrm{S}$ ) the flow was also predominantly in the offshore direction over the entire width of the shelf. The mean wind field at the surface was predominantly westerly although a northerly component was stronger over the northern portion of the shelf, equaling the westerly component $(\sim 1.5 \mathrm{~m} / \mathrm{s})$ in that region. Mean wind speeds increased southward to over $3 \mathrm{~m} / \mathrm{s}$ at $44^{\circ} \mathrm{S}$.

The subsurface mean state reflected a similar pattern as the surface, notably the confluence of the Zeehan Current and EAC Extension, but with a stronger cross-shelf structure (Figure 7c,d). At $56 \mathrm{~m}$ depth the Zeehan current was evident as a strong narrow jet against the coast south of the Tasman Peninsula while further offshore the circulation reversed and was dominated by the EAC Extension (Figure 7c, arrows). The Zeehan Current was predominantly swept offshore over the range $42.5-43^{\circ} \mathrm{S}$, as at the surface. However, it should be noted that a weaker continuation of the Zeehan Current continued northward, confined within $20 \mathrm{~km}$ of the coast. As in the south, the flow reversed offshore and was dominated by 
(a) Mean SST

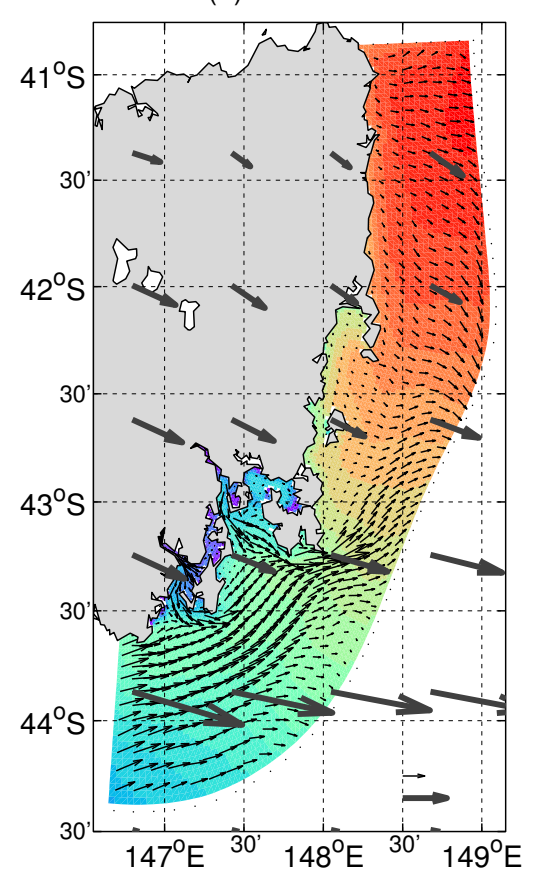

(c) Mean T (56 m)



(b) Mean SSS
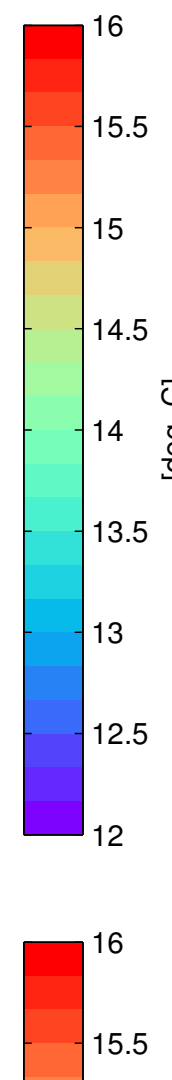

35.2

35.1

35

34.9

34.8 क

$-34.7$

34.6

34.5

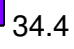

(d) Mean T (105 m)

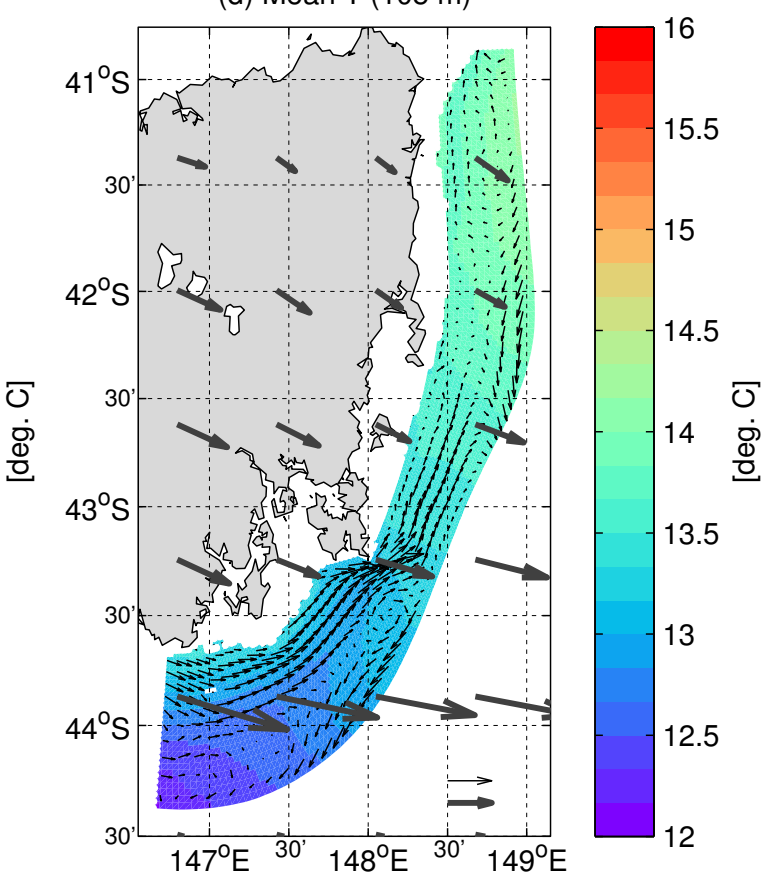

Figure 7: Mean temperature, salinity and circulation over the eastern Tasmanian Continental Shelf. Shown is the annual mean (a) surface temperature and currents, (b) surface salinity and currents, (c) temperature and currents at $56 \mathrm{~m}$ depth, and (d) temperature and currents at $105 \mathrm{~m}$ depth. Grey arrows indicate surface wind. The reference arrows in the bottom right of each panel represent $10 \mathrm{~cm} / \mathrm{s}(2 \mathrm{~m} / \mathrm{s})$ for the ocean (atmosphere). Note that only every third (second) vector, in each direction, has been plotted for oceanic (atmospheric) velocities. 
the EAC Extension. Along the shelf break at most latitudes the flow was dominated by the EAC Extension (southward flow). It appeared that the EAC Extension extended offshore at $\sim 42.5^{\circ} \mathrm{S}$ and then flowed back onshore to intensify southwards at $\sim 43.5^{\circ} \mathrm{S}$. North of $\sim 42^{\circ} \mathrm{S}$ there was substantial onshore flow, reflecting the offshore flow present at the surface. The same overall circulation pattern was also evident at $105 \mathrm{~m}$ depth (Figure $7 \mathrm{~d}$ ).

\subsection{Seasonality}

The seasonal cycle of the R/NT run was calculated as the mean state over three-month subsets of the year, across all years from 1993 to 2014 (Figures 8 and 9). The seasons were defined as: Summer (DJF), Autumn (MAM), Winter (JJA), and Spring (SON). The seasonal cycle in surface temperature was in the $15-19^{\circ} \mathrm{C}$ range in summer and in the $11-$ $14^{\circ} \mathrm{C}$ range in winter (except in the estuaries where wintertime temperatures dropped as low as $7^{\circ} \mathrm{C}$; Figure 8a-d, colours). Surface salinity also showed a seasonal cycle with higher values in summer and autumn and lower values in winter and spring (Figure $8 \mathrm{e}-\mathrm{h}$, colours). Notably, the plume of low salinity water in the estuaries reached its greatest extent, under the influence of increased freshwater runoff, in spring and smallest extent in autumn.

The seasonal cycle in surface circulation indicated an alternation between a dominant EAC Extension, peaking in summer, and a dominant Zeehan Current, peaking in winter (Figure $8 \mathrm{a}-\mathrm{h}$, arrows). In summer, the Zeehan Current was restricted to lie only south of the Tasman Peninsula and immediately retroflects southward; north and east of the Tasman Peninsula the circulation was dominated by southward flow under the influence of the EAC Extension. By autumn the Zeehan Current increased in strength and the circulation appeared similar to the annual mean. In winter, the Zeehan Current was completely dominant and northward flow persisted over the entire domain. In spring the pattern reversed and again appeared similar to the annual mean. The seasonal cycle of surface wind showed the dominance of the westerlies throughout most of the year. Wind speeds were strongest in winter and weakest in summer. South of $42.5^{\circ} \mathrm{S}$ the wind was predominantly westerly at all times of year while north of $42.4^{\circ} \mathrm{S}$ the wind was westerly or northwesterly in autumn and spring and then veered towards being nearly northerly in summer. 

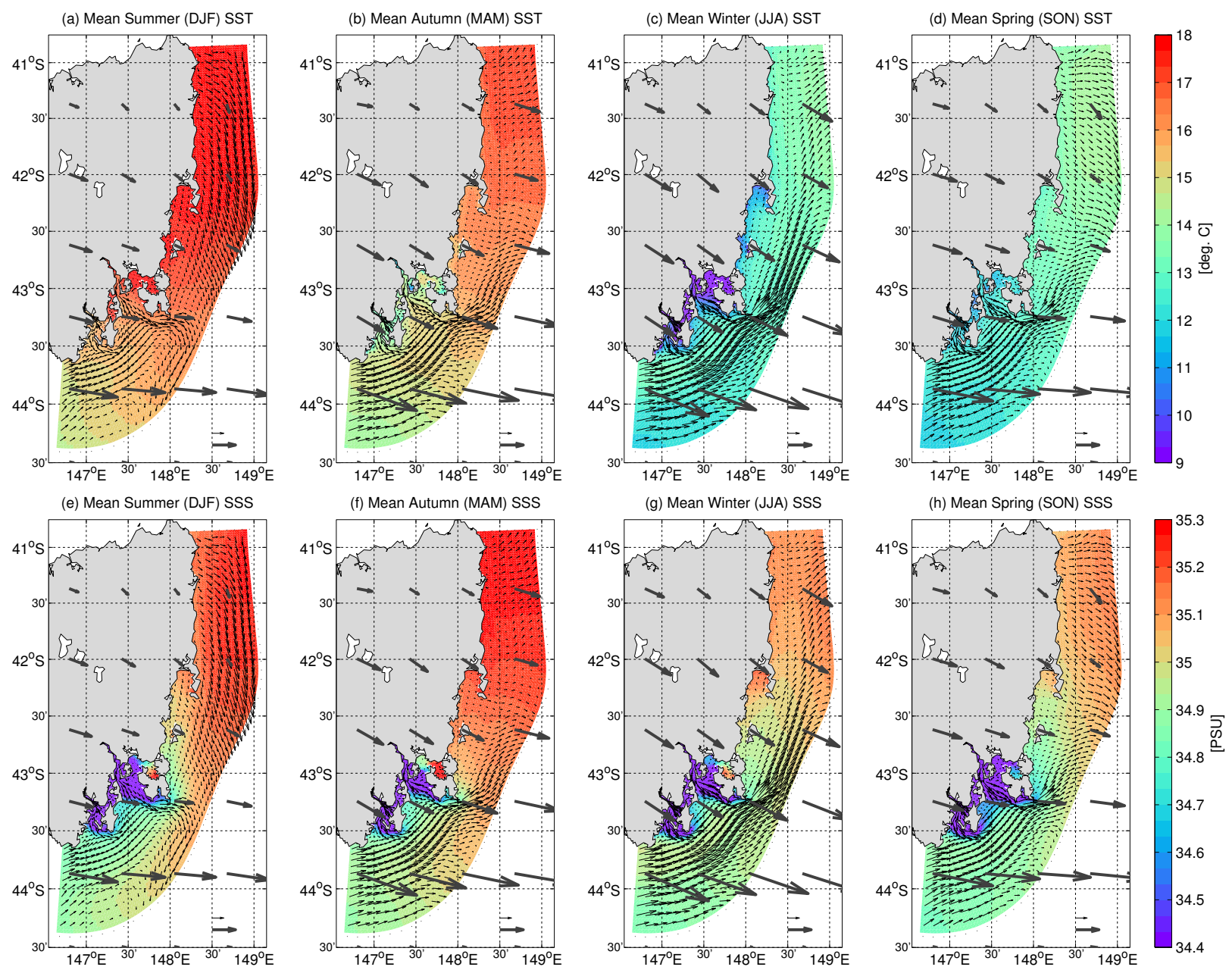

Figure 8: Seasonal cycle of surface temperature, salinity and circulation over the eastern Tasmanian Continental Shelf. Shown is the annual mean (first row) surface temperature and currents and (second row) surface salinity and currents for (first column) summer, (second column) autumn, (third column) winter, and (fourth column) spring. Grey arrows indicate surface wind. The reference arrows in the bottom right of each panel represent $10 \mathrm{~cm} / \mathrm{s}(2 \mathrm{~m} / \mathrm{s})$ for the ocean (atmosphere). Note that only every third (second) vector, in each direction, has been plotted for oceanic (atmospheric) velocities. 

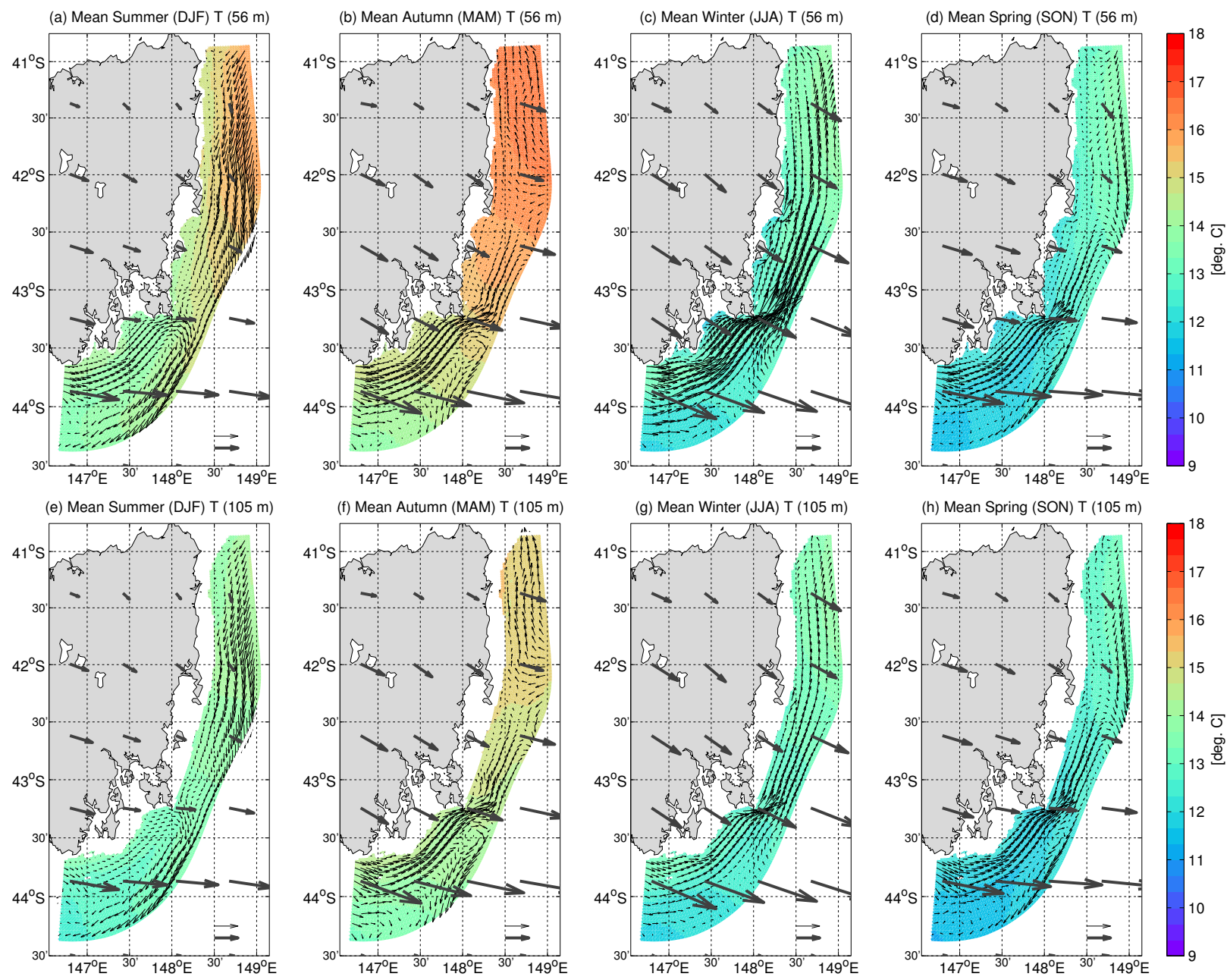

Figure 9: Seasonal cycle of subsurface temperature and circulation over the eastern Tasmanian Continental Shelf. Shown is the annual mean (first row) temperature and currents at $56 \mathrm{~m}$ depth and (second row) temperature and currents at $105 \mathrm{~m}$ depth for (first column) summer, (second column) autumn, (third column) winter, and (fourth column) spring. Grey arrows indicate surface wind. The reference arrows in the bottom right of each panel represent $10 \mathrm{~cm} / \mathrm{s}(2 \mathrm{~m} / \mathrm{s}$ ) for the ocean (atmosphere). Note that only every third (second) vector, in each direction, has been plotted for oceanic (atmospheric) velocities. 
The seasonal cycle of subsurface circulation reflected the same alternation between dominance of the EAC Extension in summer and the Zeehan Current in winter (Figure 9a-h). As with the annual mean the seasonal cycle of subsurface circulation exhibited a stronger crossshelf structure than the surface circulation. Along the shelf break and at both $56 \mathrm{~m}$ and 105 $\mathrm{m}$ depth (Figure 9a-d and 9e-h, respectively), southward flow due to the EAC Extension was clear at all latitudes in spring and summer while the Zeehan Current is dominant over the entire domain in winter. A northward coastal current was clear at both $56 \mathrm{~m}$ and $105 \mathrm{~m}$ depth in all seasons except summer, during which coastal flow was southward north of the Tasman Peninsula. Autumn exhibited a mixed pattern with no major circulation pattern dominating overall.

Three depth sections across the shelf further demonstrate the seasonal cycle of temperature and circulation (Figure 10). A cross-shelf section intersecting St. Helens in northeastern Tasmania $\left(41.2821^{\circ} \mathrm{S}, 148.3684^{\circ} \mathrm{E}\right)$ showed the seasonal alternation of the EAC Extension and Zeehan Current in the along-shelf flow (Figure 10a-d). In summer, the section was dominated by southward flow, peaking at $0.10 \mathrm{~m} / \mathrm{s}$ at around $25 \mathrm{~m}$ depth and just outside the shelf break. There appeared to be a weak northward flow $(0.02 \mathrm{~m} / \mathrm{s})$ trapped to the continental slope over the 50-100 $\mathrm{m}$ depth range: this was likely the seasonal minimum of the coastal current identified above. In autumn this northward flow over the slope intensified and by winter the section was dominated by northward flow. In spring there was a mixed circulation with southward EAC Extension flows offshore and in the upper layers and northward Zeehan Current flows in deeper and more inshore waters.

A cross-shelf section intersecting Maria Island in central Tasmania $\left(42.6873^{\circ} \mathrm{S}, 148.1148^{\circ} \mathrm{E}\right)$ also showed the seasonal alternation of the EAC Extension and Zeehan Current in the alongshelf flow (Figure 10e-h). In summer, and as for the St. Helens section, the Maria Island section was dominated by southward flow, the intensity of which increased in the offshore direction, except for the most inshore portion which exhibited a weak northward flow $(\sim 0.03$ $\mathrm{m} / \mathrm{s})$. In autumn this southward flow remained below $150 \mathrm{~m}$ and above that the flow was northward. By winter almost the entire section exhibited northward flow. The northward 

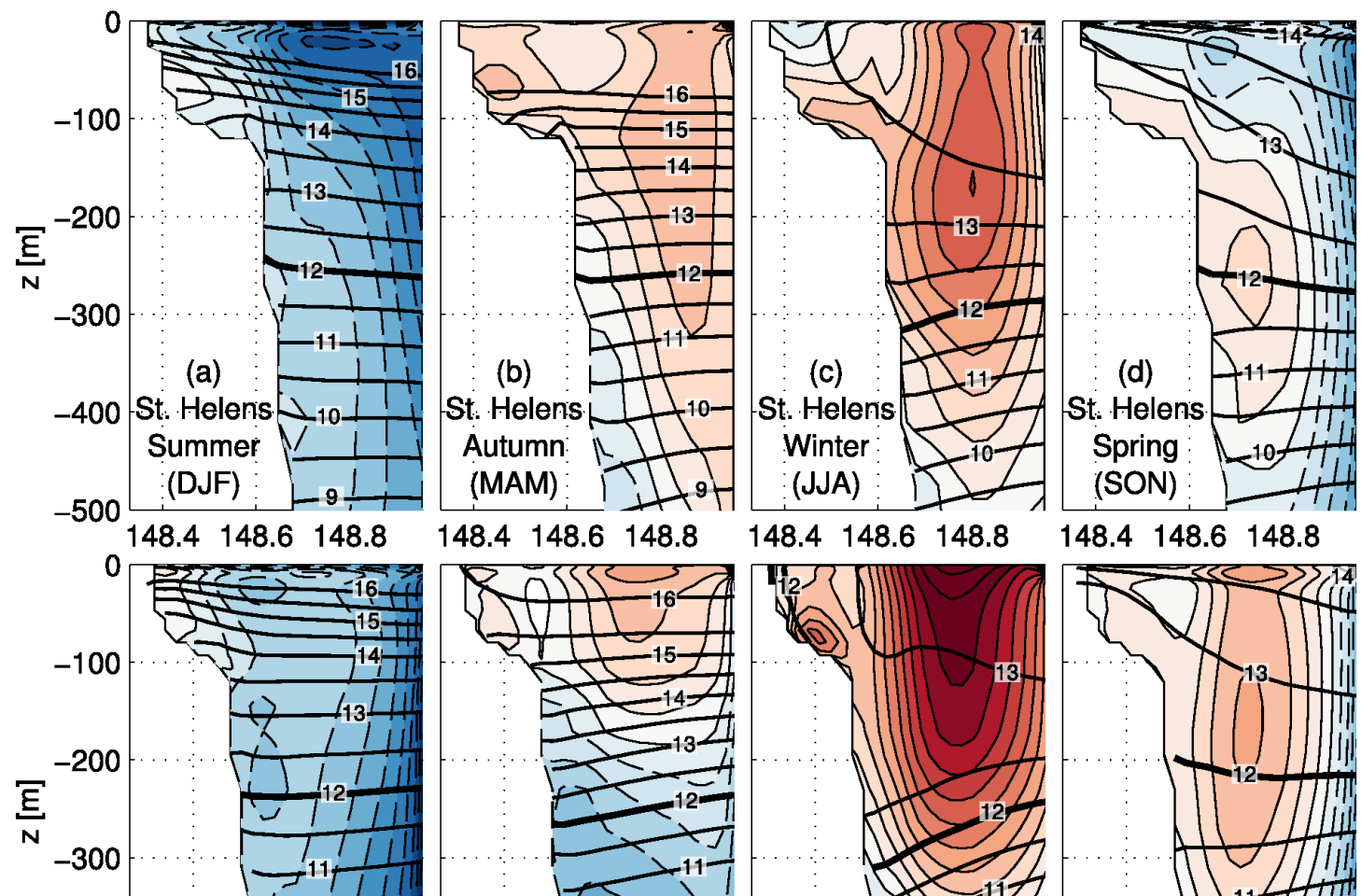

$\begin{array}{lll}148.4 & 148.6 \quad 148.8\end{array}$

(e)

-400 Maria Is. $\frac{1}{1}$ 10t TIT

Summer
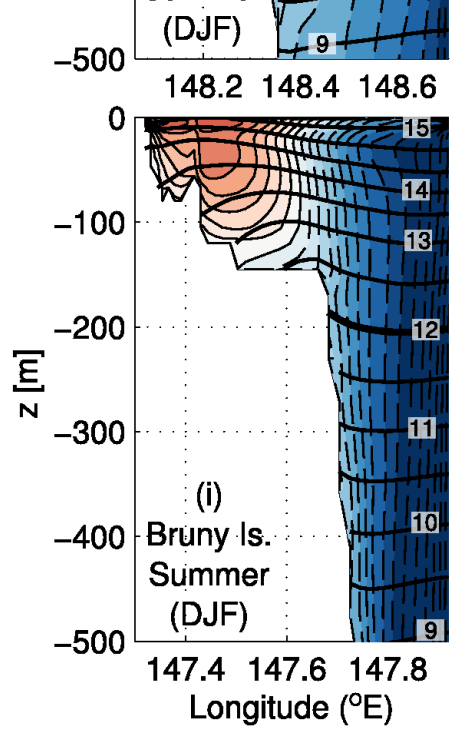

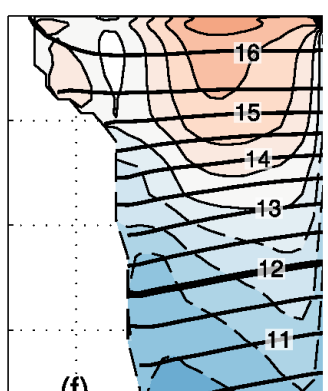

(f)

Maria Is.

Autumn

(MAM)

148.2148 .4148 .6

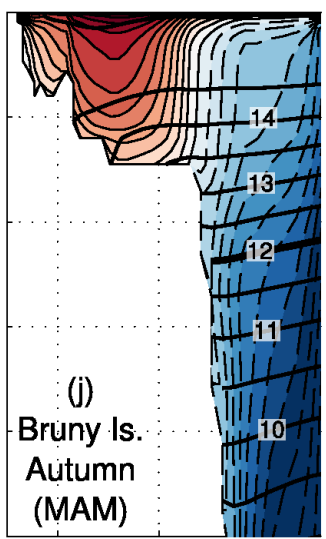

$\begin{array}{lll}147.4 & 147.6 & 147.8\end{array}$ Longitude ( $\left.{ }^{\circ} \mathrm{E}\right)$

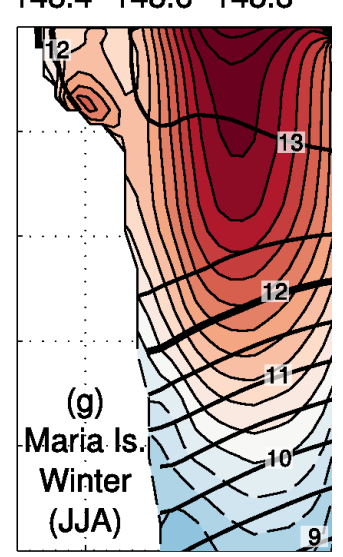

148.2148 .4148 .6

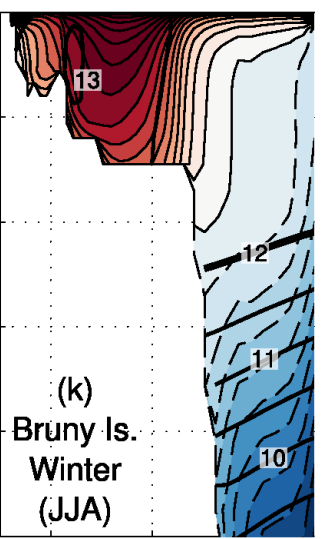

$\begin{array}{lll}147.4 & 147.6 & 147.8\end{array}$ Longitude ( $\left.{ }^{\circ} \mathrm{E}\right)$

Figure 10: Seasonal cycle of temperature and along-shore circulation across the eastern Tasmanian continental shelf. Shown are the temperature (contours) and along-shore velocity (colour-filled contours, dashed for negative values) at three sections crossing perpendicular to the continental shelf and intersecting the coast at (top) St. Helens, (middle) Maria Island, and (bottom) Bruny Island for (first column) summer, (second column) autumn, (third column) winter, and (fourth column) spring. Temperature contours are plotted every $0.5^{\circ} \mathrm{C}$; the $12^{\circ} \mathrm{C}$ contour is plotted as a thick line for reference. Section locations are shown in Figure $1 \mathrm{~b}$ (dashed lines). 
flow in winter appeared to have two cores: a stronger core offshore extending down to $400 \mathrm{~m}$ peaking at the surface $(0.13 \mathrm{~m} / \mathrm{s})$ and a weaker one $(0.062 \mathrm{~m} / \mathrm{s})$ trapped to the continental shelf between $50 \mathrm{~m}$ and $100 \mathrm{~m}$. In spring the pattern reversed again with southward flow creeping in from offshore.

Over the shelf there was a northward intensification in velocity with depth at Maria Island in Winter (Figure 10g) and at St Helens in autumn-spring (Figure 10b-d). There concurrently were stronger northerly surface winds over the northern portion of the shelf in autumn, winter, and spring (e.g., Figure 9, grey arrows). These northerlies would lead to upwelling and a consequent uplift of isotherms over the shelf, as is seen on the west coast of Tasmania under the influence of southeasterlies (Kämpf, 2015). This cross-shelf thermal gradient would lead to an increase of northward flow with depth, through the thermal wind relationship.

A cross-shelf section intersecting Bruny Island in southeastern Tasmania $\left(43.5048^{\circ} \mathrm{S}, 147.3202^{\circ} \mathrm{E}\right)$ showed the year-round dominance of the Zeehan Current over the continental shelf (Figure 10i-l). In summer there was a partition between northward Zeehan Current over the continental shelf and a southward EAC Extension offshore; both currents extended throughout the water column. In autumn the core of the Zeehan Current expanded offshore and by winter northward flow was dominant over the entire section except below $\sim 200 \mathrm{~m}$. The wintertime peak of the Zeehan Current was $0.13 \mathrm{~m} / \mathrm{s}$, located at the surface. In spring the pattern began to swing back towards summer and the core of the Zeehan Current shrank back towards the continental shelf. This was consistent with the seasonal means at depth (Figure 9).

The along-shelf volume transports at St. Helens, Maria Island, and Bruny Island were calculated by integrating the along-shelf velocities over the corresponding sections. The calculation was performed separately for transport over the shelf $\left(T_{\mathrm{sh}}\right)$ and for transport in deeper waters $\left(T_{\mathrm{dp}}\right)$ by restricting the calculation to cells inshore or offshore of the 200 $\mathrm{m}$ isobath. In addition, we were primarily interested in oceanographic flows and so all cells with depths less than $20 \mathrm{~m}$ were ignored to avoid including large flows associated with rivers. 

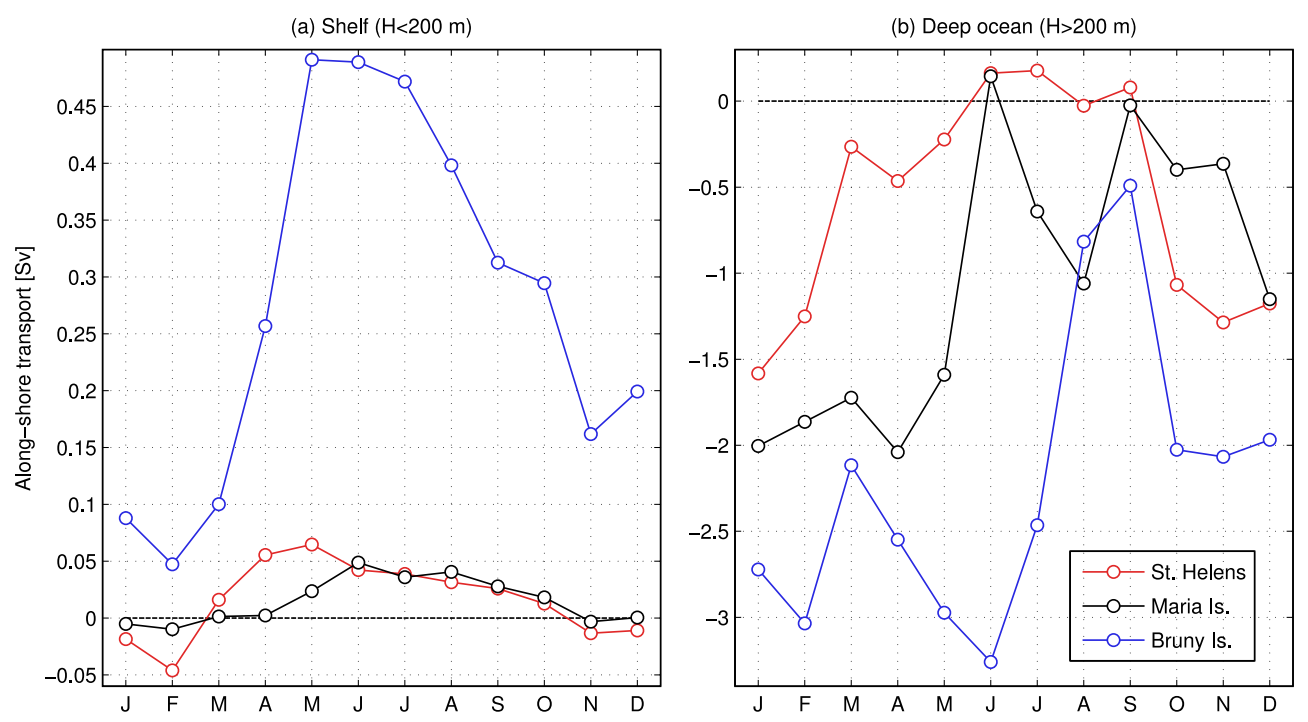

Figure 11: Seasonal cycle of along-shelf transport. Shown is a monthly climatology of shelf transport (in Sv) at three sections crossing perpendicular to the continental shelf and intersecting the coast at (red) St. Helens, (black) Maria Island, and (blue) Bruny Island. Transport is shown over the shelf (defined as the region with depths between $20 \mathrm{~m}$ and $200 \mathrm{~m}$ ) and in the deep ocean (depth greater than $200 \mathrm{~m}$ ). Sections are shown in Figure 1b (dashed lines). Zero transport is indicated by a dashed line for reference. 
A monthly climatology of $T_{\text {sh }}$ showed a seasonal cycle for all three sections (Figure 11a). All three sections had a peak in $T_{\text {sh }}$ during austral autumn and winter (March-August). Peak northward $T_{\mathrm{sh}}$ at Bruny Island was $0.49 \mathrm{~Sv}$ in March, approximately ten times the peak northward $T_{\mathrm{sh}}$ further north $(0.049 \mathrm{~Sv}$ and $0.065 \mathrm{~Sv}$ at Maria Island and St. Helens respectively). At Maria Island and Bruny Island $T_{\text {sh }}$ was weakly southward (-0.05-0 Sv) from November to February while $T_{\text {sh }}$ remained northward at Bruny Island during these months, although much weaker $(0.05-0.20 \mathrm{~Sv})$ than in other months.

Alongshore transport in deeper waters was typically larger than on the shelf, by a factor of ten, and showed a similar seasonal cycle (Figure 11b). Peak northward $T_{\mathrm{dp}}$ occurred at St. Helens, up to $0.18 \mathrm{~Sv}$ for July-September, and Maria Island, 0.14 Sv in July only, while the remainder of the year $T_{\mathrm{dp}}$ was southward peaking in January $(1.58 \mathrm{~Sv}$ at St. Helens and $2.04 \mathrm{~Sv}$ at Maria Island). At Bruny Island $T_{\mathrm{dp}}$ was southward all-year reaching a minimum of $-0.49 \mathrm{~Sv}$ in September annd a maximum of $-3.26 \mathrm{~Sv}$ in July. It is interesting to note that at Bruny Island, peak southward transport in deep water occurred during the period of strongest northward transport on the shelf.

\section{Results 2: Roles of rivers and tides}

We next examine the roles of rivers and tides on the mean state (Section 5.1) and variability (Section 5.2).

\subsection{Mean state}

The difference between the mean state of the model runs with and without rivers $(\mathrm{R} / \mathrm{NT}$ and NR/NT respectively, both without tidal forcing) was calculated to diagnose the role of rivers. The presence of rivers caused plumes of surface waters flowing onto the shelf from the Derwent and Huon estuaries to be cooler by more than $1^{\circ} \mathrm{C}$ in some regions (Figure 12a) and fresher by more than 5 PSU (Figure 12c). The rivers themselves were fresher than this (approaching 0 PSU in the upper reaches, increasing to $\sim 20$ PSU near the river mouths) and actually warmer in the presence of river inputs. Away from the estuaries there was little influence of rivers except for a region just east of Maria Island and Freycinet Peninsula 
(a) Mean SST Difference: R/NT - NR/NT

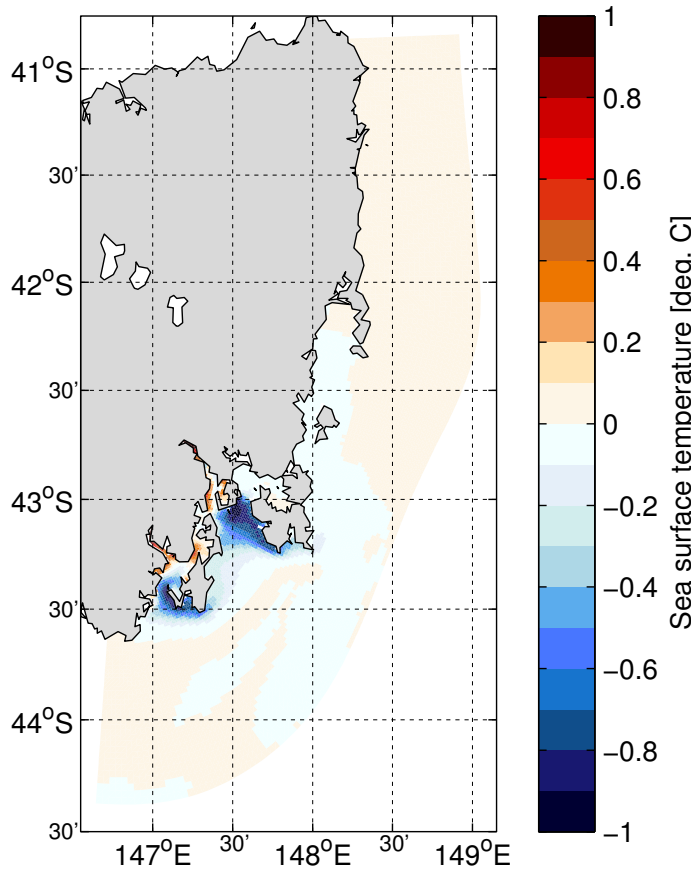

(c) Mean SSS Difference: R/NT - NR/NT

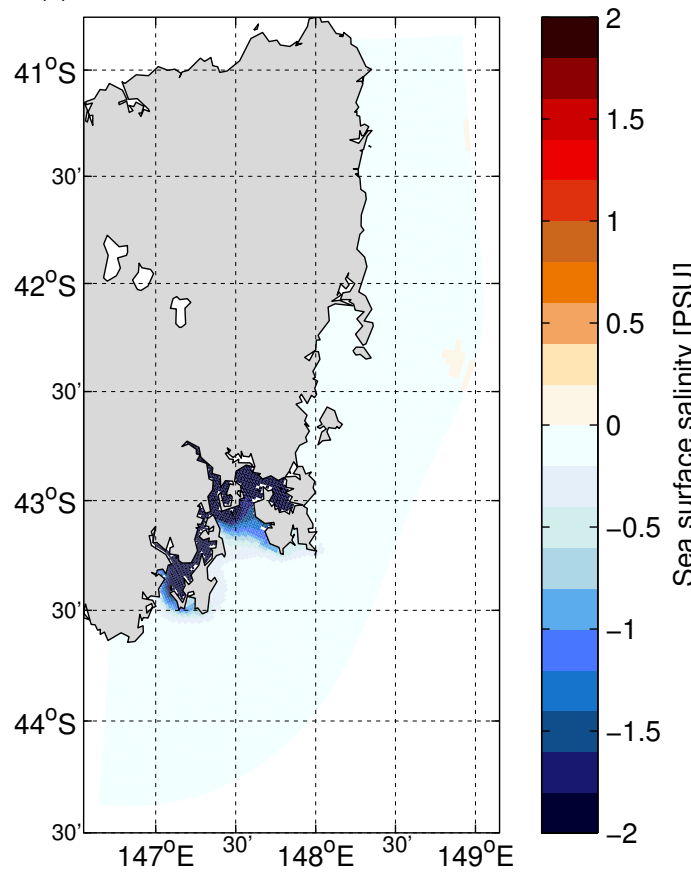

(b) Mean SST Difference: R/T - R/NT

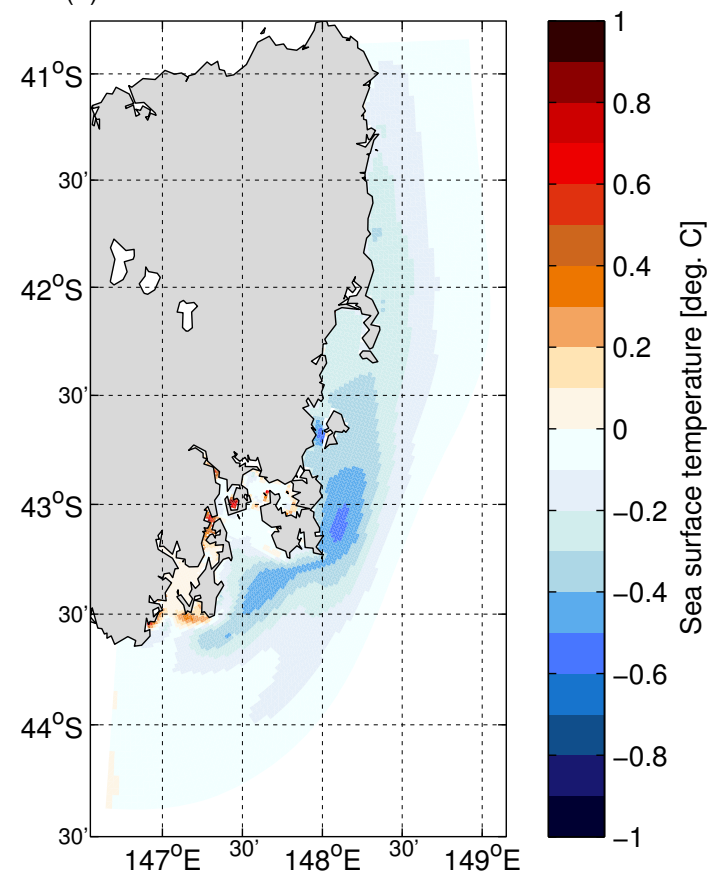

(d) Mean SSS Difference: R/T - R/NT

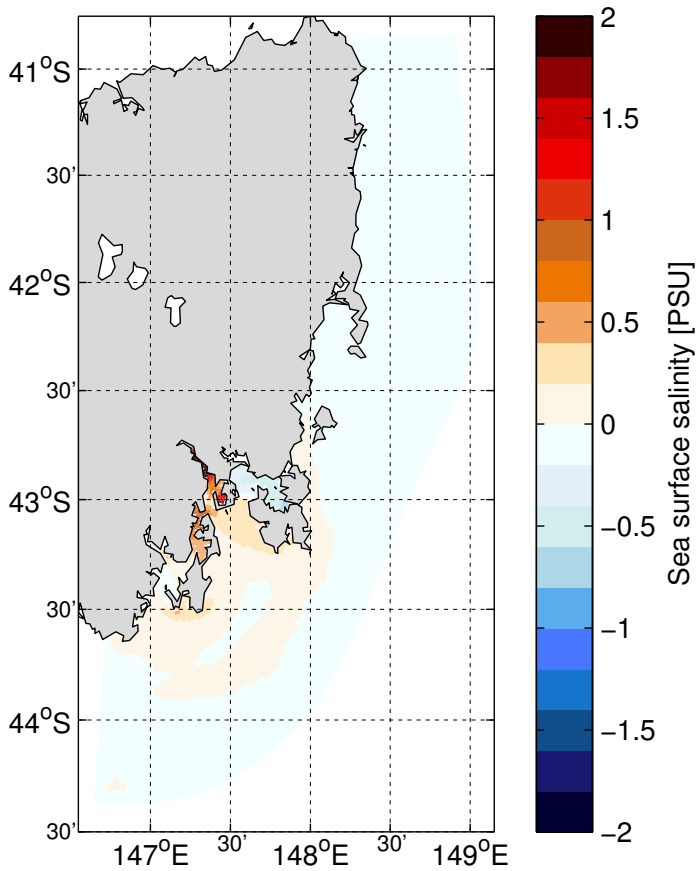

Figure 12: Role of rivers and tides on the mean state. Shown are the difference of (top) mean SST and (bottom) mean SSS between the (left) R/NT and NR/NT runs (showing the role of rivers) and the (right) $\mathrm{R} / \mathrm{T}$ and $\mathrm{R} / \mathrm{NT}$ runs (showing the role of tides). 
where surface temperatures were $\sim 0.2^{\circ} \mathrm{C}$ warmer in the presence of rivers, which was likely warm water blocked from flowing into the estuaries due to the river outflow.

The difference between the mean state of the $\mathrm{R} / \mathrm{T}$ and $\mathrm{R} / \mathrm{NT}$ runs was calculated to diagnose the role of tides. The presence of tides caused a general surface cooling of up to $1^{\circ} \mathrm{C}$ over much of the domain, which peaked just east of the Tasman Peninsula (Figure 12b). Surface waters in the estuaries were generally saltier by up to 2 PSU in the presence of tides, likely due to tidally-forced vertical mixing of saline offshore waters overcoming stratification into the otherwise fresher surface estuary waters (Figure 12d). Notably, two shallow bays which are linked to the Derwent estuary by a narrow passageway, Frederick Henry Bay and Norfolk Bay, were fresher by $\sim 0.5$ PSU in the presence of tides. This was most likely due to tidal currents through the narrow passageway enabling the flushing of relatively fresh water from the Derwent estuary into the otherwise saline bays, indicative of a coupling between the tides and rivers in this region.

\subsection{Variability}

Time series of temperature over a two-year period from the R/T, R/NT, and NR/NT runs at four stations demonstrate the difference in time variability due to rivers and tides (Figure 13). Time series have had variability on tidal time scales removed using a 39-point Doodson X0 filter (Doodson, 1928) and the seasonal cycle (including the mean) removed by harmonic regression. Generally the time series from the $\mathrm{R} / \mathrm{T}$ run (presence of rivers and tides, black line), the R/NT run (presence of rivers without tides, blue line), and the NR/NT run (no rivers or tides, red line) were similar. There were a number of occasions where the time series diverged (i.e., Feb-Aug 1993 for Bicheno and Maria Island). This can primarily be attributed to the absence of rivers in the NR/NT run causing it to diverge from the other two runs, which both had river runoff. However, differences between the $\mathrm{R} / \mathrm{T}$ and $\mathrm{R} / \mathrm{NT}$ time series indicated that the presence or absence of tides could also influence transient temperature variability (i.e., May-June 1993 at Maria Island where significant differences can be seen between all three runs).

The roles of rivers and tides on temperature variability were explored for each of the 

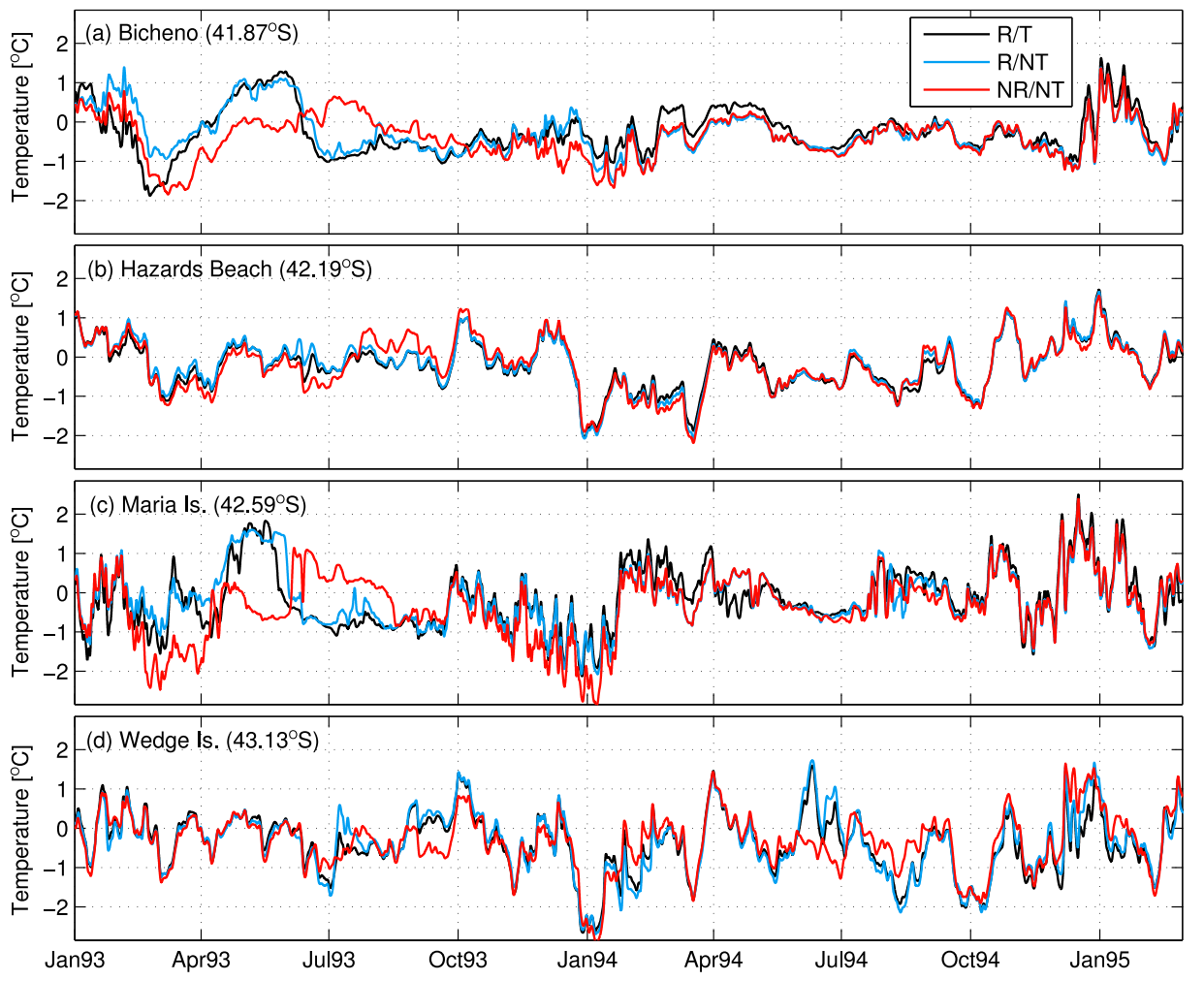

Figure 13: Time series of temperature over a two-year period at four stations. Time series are shown for (a) Bicheno, (b) Hazards Beach, (c) Maria Island, and (d) Wedge Island from the R/T (black line), R/NT (blue line), and NR/NT (red line) runs. 
(a) Influence of rivers on SST variability: RMS(R/NT - NR/NT)(b) Influence of tides on SST variability: RMS(R/T - R/NT)
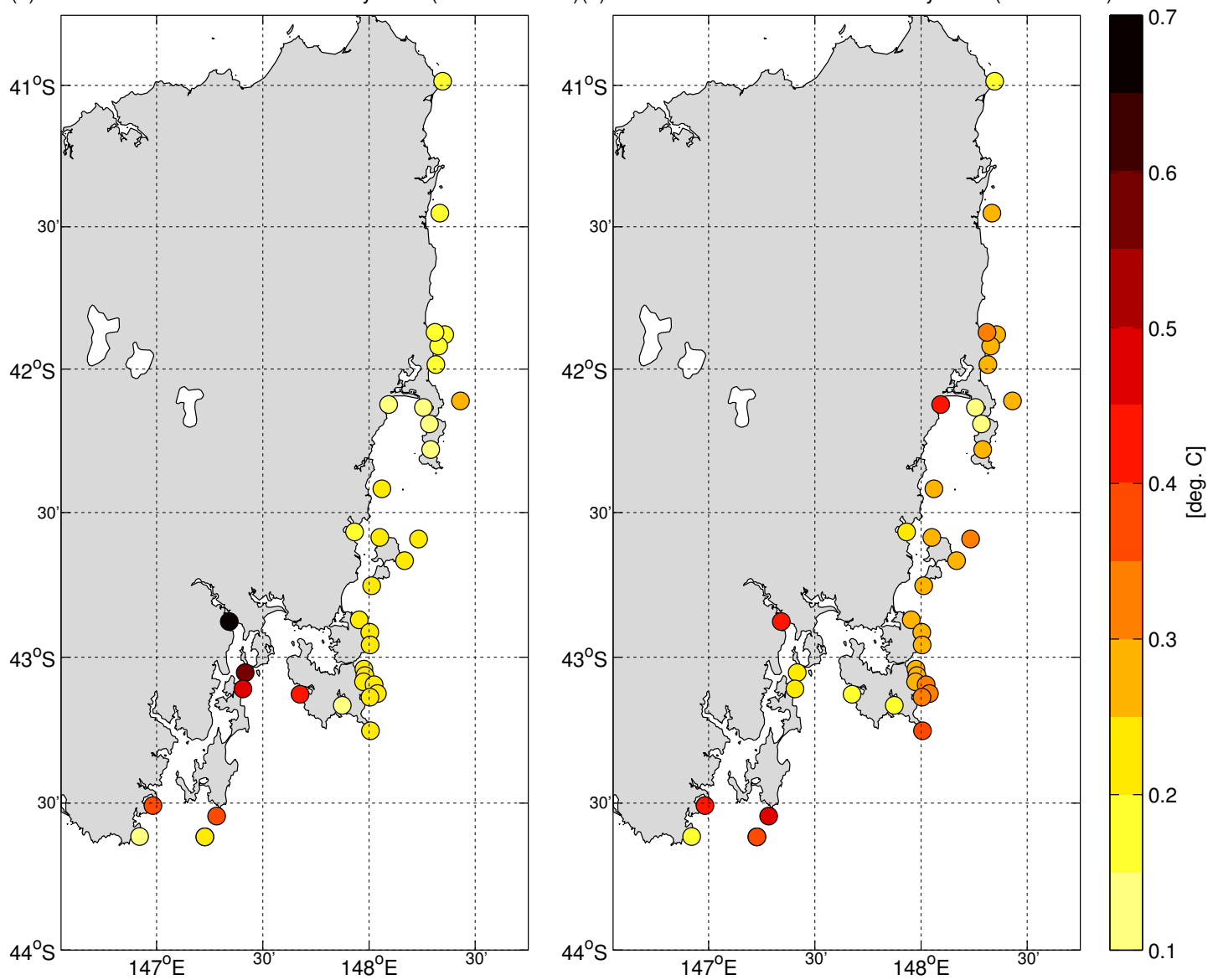

Figure 14: Role of rivers and tides on temperature variability. Shown are the RMS errors between (left) the $\mathrm{R} / \mathrm{NT}$ and NR/NT runs (showing the role of rivers) and (right) the $\mathrm{R} / \mathrm{T}$ and $\mathrm{R} / \mathrm{NT}$ runs (showing the role of tides). Note that variability on tidal time scales have been removed, so differences are for variability on non-tidal time scales. 
sites for which hourly model output time series were available (Section 2.2). For each site, the hourly time series have had the tidal and seasonal variability removed as above and the root mean square (RMS) error calculated between pairs of model runs. The magnitude of this error measures the degree to which rivers and/or tides influence temperature variability. Note that this is not measuring the variability on tidal time scales, since this has been removed, but in fact variability on non-tidal time scales which itself may be influenced by rivers or tides. The influence of rivers was calculated from the RMS error between the R/NT and NR/NT runs (Figure 14a). Unsurprisingly, the influence is strongest $\left(>0.7^{\circ} \mathrm{C}\right)$ at the most upriver site (Hobart) and most sites in the estuaries show a strong influence $\left(\sim 0.5^{\circ} \mathrm{C}\right)$. However, even well outside the estuaries and as far north as Bicheno the presence of rivers affects temperature variability on the order of $0.2-0.3^{\circ} \mathrm{C}$. The role of tides is variable across the domain ranging from $0.5-0.7^{\circ} \mathrm{C}$ at some of the estuary sites, $0.3-0.5^{\circ} \mathrm{C}$ at the more exposed sites along the coast, and $<0.3^{\circ} \mathrm{C}$ at the many of the more sheltered inshore sites (Figure 14a).

\section{Summary and discussion}

A high-resolution, three-dimensional ocean model (ETAS) was used to simulate marine climate variations over the continental shelf and slope off eastern Tasmania over the 19932014 period. The ETAS model evaluated well against remotely-sensed sea surface temperatures (SSTs) and in-situ observations of sea level and subsurface temperature, salinity, and currents. The mean state indicated a clear influence of two large-scale ocean currents (the East Australian Current, EAC, and the Zeehan Current, ZC) and local freshwater input due to river runoff. The seasonal variations were such that the EAC Extension was dominant in summer and the ZC was dominant in winter; the EAC Extension was increasingly dominant toward the north and offshore. River runoff impacted the temperature and salinity of the Derwent and Huon estuaries but had little influence on the mean state in coastal regions further north. Tidal forcing generally did not impact the mean state except to freshen Frederick Henry Bay and Norfolk Bay whereby tide-river coupling acted to flush the bays with relatively fresh river runoff. 
Eastern Tasmania is the meeting point between two Australian boundary currents (Wyrtki, 1960; Harris et al., 1987; Cresswell, 2000; Ridgway, 2007b): the EAC Extension which is a southward extension of the South Pacific Gyre western boundary current and the ZC which is the final component in a series of boundary currents stretching back to the Leeuwin Current off Western Australia. This leads to the waters around Tasmania being a seasonallyvarying mix of subtropical and subantarctic waters. The ETAS model provides the first high-resolution look at circulation over the entire eastern continental shelf off Tasmania. Further, our analysis of this simulation provides new insights into the mean state and seasonal cycle of temperature, salinity, and circulation in this region. One of the key findings of this study is the latitudinal structure and seasonal cycle of the overall circulation off eastern Tasmania. Northern and central regions (represented by St. Helens and Maria Island respectively) showed southward transport over the shelf from November to February and northward transport for the rest of the year (March-October). Southern regions (represented by Bruny Island) showed that flow on the shelf was always northward but was weakest in November-February when the EAC influence was strongest.

The ETAS model also allows us to examine cross-shelf and vertical variations in circulation over the shelf. Figure 15 presents a schematic of the mean and seasonal circulation over the shelf at the surface and in the subsurface (50-100 $\mathrm{m}$ depth). In the annual mean, the meeting point of the EAC and the ZC lies between Maria Island and Freycinet, consistent with previous estimates (Harris et al., 1987; Cresswell, 2000; Ridgway, 2007b), both at the surface and in the subsurface. Seasonal changes show this meeting point moving as far south as the Tasman Peninsula in summer and north of northeastern Tasmania in winter. The southward retroflection of the $\mathrm{ZC}$ after meeting the $\mathrm{EAC}$ is closer to the coast in the subsurface flow than the surface flow. It is also notable that across all seasons there is a subsurface northward flow trapped near the coast, possibly driven by wind-forced, cross-shelf thermal gradients. This northward coastal current may have significant impacts on marine ecosystems by allowing cold-water species to disperse larvae up the coast. This current has not been observed or reported in other modelling studies and therefore should be investigated 
further.

There are risks currently being faced by the marine ecosystems that inhabit the continental shelf waters off eastern Tasmania. The region is warming at nearly four times the global-average rate and impacts have already been felt through loss of the local giant kelp Macrocystis pyrifera and through range expansions of the warm water sea urchin Centrostephanus rodgersii (e.g., Johnson et al. (2011)). The ETAS model recovers the long-term trends in warming and salinification (not shown) observed at Maria Island (e.g., Ridgway (2007a)) and therefore can play a role in understanding the mechanisms driving marine climate changes in the region. Future work using the ETAS model will include investigations of the (i) forcing mechanisms for the northward coastal current and assessment of whether the flow is independent from the Zeehan Current or represents its northward extension, (ii) interannual variability and long-term trends of the marine climate across Tasmania's eastern continental shelf, the role of climate modes, and as a regional downscaling of large-scale ocean climate simulations, (iii) influence of EAC eddies on the continental shelf, and (iv) local and remote drivers of near-shore "marine heatwaves". In addition, the model simulation output from the ETAS model will be made publicly available and updates to the R/NT run (river runoff, no tidal forcing) will be ongoing (i.e., simulation years 2015 and onwards).

\section{Acknowledgements}

The authors would like to acknowledge funding from the Australian Research Council (ARC) Super Science Fellowship (grant no. FS110200029) and the ARC Centre of Excellence for Climate System Science (ARCCSS; grant no. CE110001028). NOAA High Resolution SST data provided by the NOAA/OAR/ESRL PSD, Boulder, Colorado, USA from their Web site at http://www.esrl.noaa.gov/psd/. Maria Island NRS, Storm Bay SRS, and Slocum glider data were sourced from the Integrated Marine Observing System (IMOS) - IMOS is a national collaborative research infrastructure, supported by the Australian Government. Near-bottom temperature logger data were provided by Dr. Craig Mundy (Fisheries and 

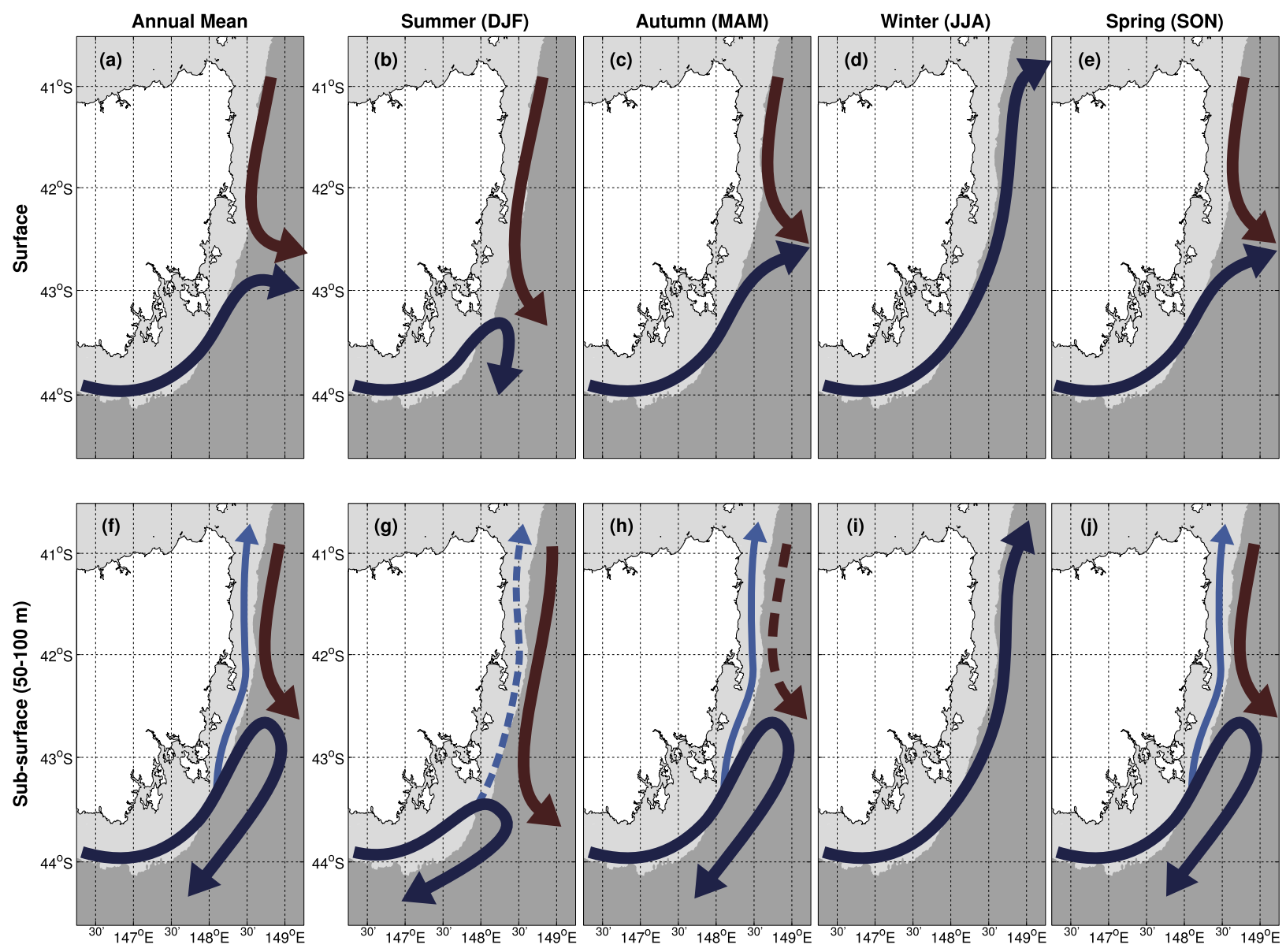

Figure 15: Schematic of surface and subsurface circulation on the eastern Tasmanian continental shelf. The red arrow indicates the EAC Extension, the dark blue arrow indicates the Zeehan Current, and the light blue arrow indicates the northward coastal current. Dashed arrows indicate currents that are not clearly represented as a continuous flow in the model simulations. The light grey area indicates water depths less than $200 \mathrm{~m}$. 
Aquaculture, Institute for Marine and Antarctic Studies, University of Tasmania). The Sparse Hydrodynamic Ocean Code (SHOC) was kindly provided by CSIRO Oceans and Atmosphere and licensed for use by IMAS/UTAS for the purposes of this research. The authors would like to acknowledge Mark Baird, John Andrewartha, Farhan Rizwi (CSIRO Marine and Atmospheric Research), and Jessica Benthuysen (Australian Institute of Marine Science) for helpful discussions and assistance setting up the numerical ocean modeling.

\section{Appendix A. Reconstruction of historical river flow and temperature}

In order to properly specify the boundary conditions of the $\mathrm{R} / \mathrm{NT}$ and $\mathrm{R} / \mathrm{T}$ model runs we require estimates of river flow and river water temperatures for the Derwent and Huon Rivers over the 1993-2014 period. Observations for river flow and temperature do exist for both rivers but over a shorter time period than required for the simulation (see Table A.8 and Figure A.16, black lines). We have therefore reconstructed historical river flow and temperature using these observations and historical climate predictors taken from CFSR. River flow is largely determined by total rainfall over the watershed and water temperature can be closely approximated from local air temperature although in both cases the response of the river to the meteorology should consist not of an instantaneous one but rather an integration over the past several hours/days/weeks.

River flow has been reconstructed from 1993 to 2014 based on the following lagged regression onto time series of precipitation over the watershed:

$$
\log \left(F_{t}-F_{\min }\right)=\alpha+\sum_{l=0}^{L} \beta_{l} \log \left(P_{t-l}\right)
$$

where $F_{t}$ is the river flow, $t$ is a time index, $\alpha$ is a constant offset, the $\left\{\beta_{l} \mid l=0 \ldots L\right\}$ are regression coefficients, $P_{t-l}$ is precipitation at some lag $l$ prior to the time $t$, and $L$ is the maximum number of lags to include in the model. Both $F_{t}$ and $P_{t}$ are distributed exponentially and so we have performed a logarithmic transformation of both variables. Also, note that while $P_{t}$ has a minimum of zero, $F_{t}$ can have a non-zero and positive minimum value, $F_{\min }$, particularly if the river flow is controlled (e.g., by a hydro-electric authority as is 
the case for the Derwent River). In this case we have subtracted $F_{\min }$ from $F_{t}$ prior to fitting the model; this value is then added back to the model predictions $\hat{F}_{t}$. We used a value of $F_{\min }=30 \mathrm{~m}^{3} \mathrm{~s}^{-1}$ for the Derwent River and $F_{\min }=0 \mathrm{~m}^{3} \mathrm{~s}^{-1}$ for the Huon River. Predictors $\left(P_{t}\right)$ were 6-hourly time series of precipitation extracted from CFSR/CFSv2 at locations in high-rainfall areas of the river catchments: $\left[42.0397^{\circ} \mathrm{S}, 146.4938^{\circ} \mathrm{E}\right]$ for the Derwent River and $\left[43.0725^{\circ} \mathrm{S}, 146.5213^{\circ} \mathrm{E}\right]$ for the Huon River (see Figure A.16, black outline and blue squares). The maximum number of lags to include in the model, $L$, was determined by a twofold cross validation. The observed record was split into two halves, a training half and a validation half, and the model was fit to the former and evaluated using a correlation coefficient over the latter. This was then repeated by switching the halves and an average validation correlation coefficient was calculated. This procedure was done for all values of $L$ from 1 day to 50 days and the optimum value was determined as that which yielded the largest validation correlation coefficient. This was found to be 15 days for Derwent River flow and 5 days for Huon river flow. The model was then fit over the full observed record, with correlation coefficients of 0.67 for the Derwent River and 0.65 for the Huon River, and hindcast over the 1993-2014 period (denoted $\hat{F}_{t}$ ). We noted that the model predictions provided a good fit to sub-seasonal variability (i.e., flood events) but it did not provide an ideal fit for the seasonal cycle. We have therefore removed the seasonal cycle, calculated by harmonic regression, from $\hat{F}_{t}$ and replaced it with the seasonal cycle of $F_{t}$, also calculated by harmonic regression, hindcast over the 1993-2014 period. In doing so we have improved the fit of $\hat{F}_{t}$ to the the observed record, with correlation coefficients of 0.73 for the Derwent River and 0.69 for the Huon River (Figure A.16, red lines).

River temperature was reconstructed from 1993 to 2014 using a lagged regression onto time series of local air temperature

$$
T_{t}^{\mathrm{riv}}=\alpha+\sum_{l=0}^{L} \beta_{l} T_{t-l}^{\mathrm{air}}
$$

where $T_{t}^{\text {riv }}$ is the river temperature, $T_{t}^{\text {air }}$ is local air temperature, and $t, \alpha,\left\{\beta_{l} \mid l \ldots L\right\}$, and $l$ have the same meaning as in Equation A.1. Unlike the river flow model described above we have not log-transformed the predictors and predictands and we found no need to replace the 
Table A.8: Observed river flow rates and water temperatures. Observation locations for flow rates and temperatures are shown in Figure A.16 by blue and red circles respectively.

\begin{tabular}{|c|ccc|c|ccc|}
\hline River & Location & Latitude & Longitude & Variable & Start & End & Rate \\
\hline Derwent & New Norfolk & $42.78^{\circ} \mathrm{S}$ & $147.06^{\circ} \mathrm{E}$ & Flow $\left[\mathrm{m}^{3} \mathrm{~s}^{-1}\right]$ & $17 / 11 / 2009$ & $25 / 9 / 2013$ & Hourly \\
Huon & Frying Pan & $43.04^{\circ} \mathrm{S}$ & $146.85^{\circ} \mathrm{E}$ & Flow $\left[\mathrm{m}^{3} \mathrm{~s}^{-1}\right]$ & $17 / 11 / 2009$ & $31 / 12 / 2013$ & Hourly \\
\hline Derwent & Meadowbank & $42.77^{\circ} \mathrm{S}$ & $147.07^{\circ} \mathrm{E}$ & Temp. $\left[{ }^{\circ} \mathrm{C}\right]$ & $2 / 8 / 2012$ & $11 / 6 / 2014$ & Hourly \\
Huon & Judbury & $43.00^{\circ} \mathrm{S}$ & $146.93^{\circ} \mathrm{E}$ & Temp. $\left[{ }^{\circ} \mathrm{C}\right]$ & $1 / 4 / 2009$ & $6 / 5 / 2009$ & Hourly \\
\hline
\end{tabular}

predicted seasonal cycle. Predictors $\left(T_{t}^{\text {air }}\right)$ were 6-hourly time series of $10 \mathrm{~m}$ air temperature extracted from CFSR/CFSv2 at the same location as the observed river temperatures (see Table A.8). We performed model validation and determined the maximum number of lags $L$ as above and found the best fit for $L=20$ days for the Derwent River and $L=3$ days for the Huon River. Correlation coefficients over the full observed record were 0.95 for the Derwent River and 0.90 for the Huon River (Figure A.16, red lines).

\section{References}

ABARE, 2014. Australian fisheries and aquaculture statistics 2013, Research by the Australian Bureau of Agricultural and Resource Economics and Sciences. Commonwealth of Australia.

Baines, P. G., Edwards, R. J., Fandry, C. B., 1983. Observations of a new baroclinic current along the western continental slope of Bass Strait. Marine and Freshwater Research 34 (1), $155-157$.

Bennett, S., Wernberg, T., Connell, S. D., Hobday, A. J., Johnson, C. R., Poloczanska, E. S., 2015. The 'Great Southern Reef': social, ecological and economic value of Australia's neglected kelp forests. Marine and Freshwater Research.

Bolton, D., 1980. The computation of equivalent potential temperature. Monthly Weather Review 108 (7), 1046-1053. 

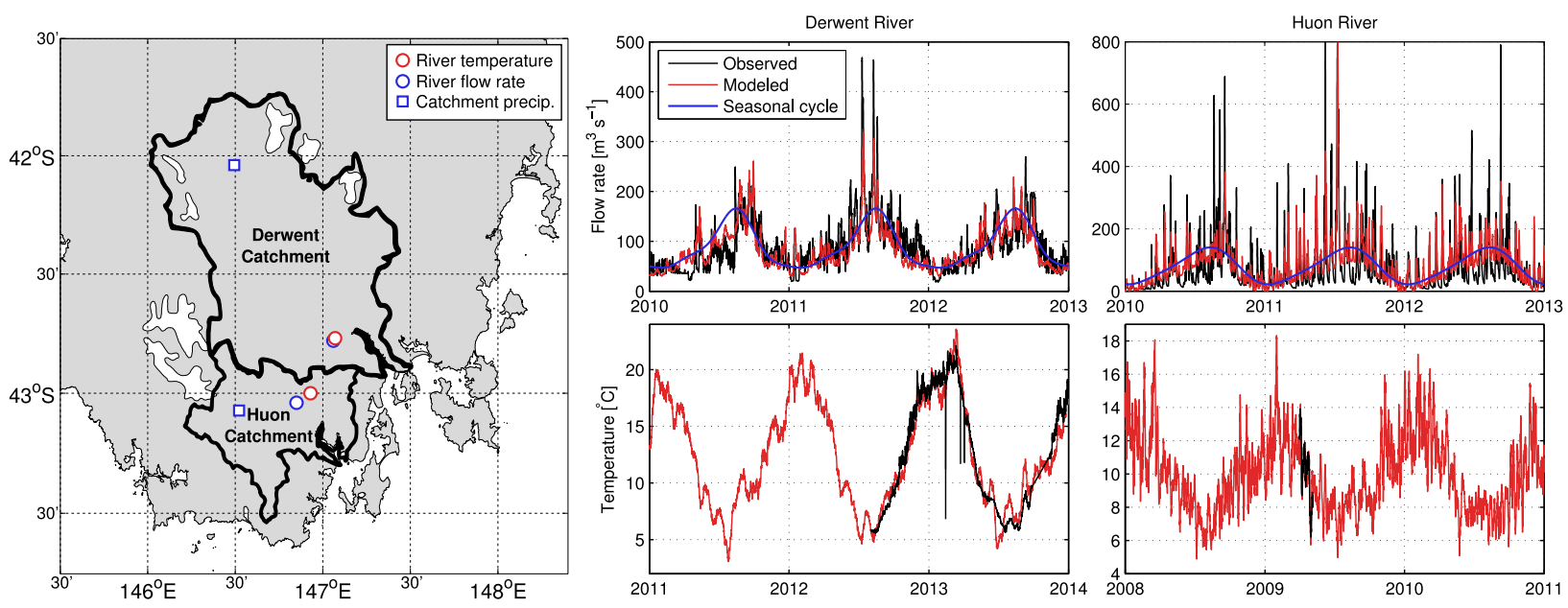

Figure A.16: Observed and estimated river flow and water temperature. The map shows the extent of the river catchments and the locations of observed river flow rates (blue circles), observed water temperatures (red circles), and precipitation predictor time series (blue squares). In the time series plots observations are shown in black, estimates of the seasonal cycle in blue, and the model predictions in red.

Burchard, H., Petersen, O., Rippeth, T. P., 1998. Comparing the performance of the MellorYamada and the $\kappa-\varepsilon$ two-equation turbulence models. Journal of Geophysical Research 103 (C5), 10543-10554.

Cresswell, G., 2000. Currents of the continental shelf and upper slope of Tasmania. In: Papers and Proceedings of the Royal Society of Tasmania. Vol. 133. pp. 21-30.

Doodson, A., 1928. The analysis of tidal observations. Royal Society of London Philosophical Transactions Series A 227, 223-279.

Eanes, R., Bettadpur, S., 1995. The CSR 3.0 global ocean tide model, Tech. Memo. CSRTM-95-06, Cent. for Space Res., Univ. of Tex., Austin.

Harris, G., Nilsson, C., Clementson, L., Thomas, D., 1987. The water masses of the east coast of Tasmania: seasonal and interannual variability and the influence on phytoplankton biomass and productivity. Marine and Freshwater Research 38 (5), 569-590. 
Herzfeld, M., 2006. An alternative coordinate system for solving finite difference ocean models. Ocean Modelling 14 (3), 174-196.

Herzfeld, M., Andrewartha, J., Sakov, P., 2010a. Modelling the physical oceanography of the D'Entrecasteaux Channel and the Huon Estuary, south-eastern Tasmania. Marine and Freshwater Research 61 (5), 568-586.

Herzfeld, M., Andrewartha, J. R., 2012. A simple, stable and accurate Dirichlet open boundary condition for ocean model downscaling. Ocean Modelling 43, 1-21.

Herzfeld, M., Jones, E., Margvelashvili, N., Mongin, M., Skerratt, J., Andrewartha, J., Rizwi, F., McAlister, T., Holmes, R., Barry, M., Weber, T., Teakle, I., 2012. SEQ RWQM V3 Phase II Final Report to SEQ Healthy Waterways. CSIRO.

Herzfeld, M., Waring, J., Parslow, J., Margvelashvili, N., Sakov, P., Andrewartha, J., 2010b. SHOC: Sparse Hydrodynamic Ocean Code Scientific Manual.

Holbrook, N. J., Bindoff, N. L., 1997. Interannual and decadal temperature variability in the southwest Pacific Ocean between 1955 and 1988. Journal of Climate 10 (5), 1035-1049.

Johnson, C. R., Banks, S. C., Barrett, N. S., Cazassus, F., Dunstan, P. K., Edgar, G. J., Frusher, S. D., Gardner, C., Haddon, M., Helidoniotis, F., et al., 2011. Climate change cascades: shifts in oceanography, species' ranges and subtidal marine community dynamics in eastern Tasmania. Journal of Experimental Marine Biology and Ecology 400 (1), 17-32.

Jones, E. M., Oke, P. R., Rizwi, F., Murray, L. M., 2012. Assimilation of glider and mooring data into a coastal ocean model. Ocean Modelling 47, 1-13.

Kämpf, J., 2015. Phytoplankton blooms on the western shelf of Tasmania: evidence of a highly productive ecosystem. Ocean Science 11 (1), 1-11.

Kondo, J., 1975. Air-sea bulk transfer coefficients in diabatic conditions. Boundary-Layer Meteorology 9 (1), 91-112. 
Large, W. G., Pond, S., 1981. Open ocean momentum flux measurements in moderate to strong winds. Journal of Physical Oceanography 11 (3), 324-336.

Large, W. G., Yeager, S. G., 2004. Diurnal to decadal global forcing for ocean and sea-ice models: the data sets and flux climatologies, Technical Report TN-460+STR, NCAR.

Leonard, B. P., 1979. A stable and accurate convective modelling procedure based on quadratic upstream interpolation. Computer Methods in Applied Mechanics and Engineering 19 (1), 59-98.

Leonard, B. P., 1991. The ULTIMATE conservative difference scheme applied to unsteady one-dimensional advection. Computer Methods in Applied Mechanics and Engineering $88(1), 17-74$.

Mayfield, S., Mundy, C., Gorfine, H., Hart, A. M., Worthington, D., 2012. Fifty years of sustained production from the Australian abalone fisheries. Reviews in Fisheries Science $20(4), 220-250$.

Middleton, J. F., Cirano, M., 2005. Wintertime circulation off southeast Australia: Strong forcing by the East Australian Current. Journal of Geophysical Research 110 (C12).

Oke, P. R., Sakov, P., Cahill, M. L., Dunn, J. R., Fiedler, R., Griffin, D. A., Mansbridge, J. V., Ridgway, K. R., Schiller, A., 2013. Towards a dynamically balanced eddy-resolving ocean reanalysis: BRAN3. Ocean Modelling 67, 52-70.

Oliver, E. C. J., Holbrook, N. J., 2014. A statistical method for improving continental shelf and near-shore marine climate predictions. Journal of Atmospheric and Oceanic Technology 31, 216-232.

Pawlowicz, R., Beardsley, B., Lentz, S., 2002. Classical tidal harmonic analysis including error estimates in MATLAB using T_TIDE. Computers \& Geosciences 28 (8), 929-937.

Pecl, G. T., Frusher, S. D., Gardner, C., Haward, M., Hobday, A. J., Jennings, S., NurseyBray, M., Punt, A. E., Revill, H., Van Putten, I. E., 2009. The east coast Tasmanian rock 
lobster fishery-vulnerability to climate change impacts and adaptation response options. Report to the Department of Climate Change, Canberra. Commonwealth of Australia.

Reynolds, R. W., Smith, T. M., Liu, C., Chelton, D. B., Casey, K. S., Schlax, M. G., 2007. Daily high-resolution-blended analyses for sea surface temperature. Journal of Climate $20(22), 5473-5496$.

Ridgway, K. R., 2007a. Long-term trend and decadal variability of the southward penetration of the East Australian Current. Geophysical Research Letters 34 (13), L13613.

Ridgway, K. R., 2007b. Seasonal circulation around Tasmania: an interface between eastern and western boundary dynamics. Journal of Geophysical Research 112 (C10).

Saha, S., Moorthi, S., Pan, H.-L., Wu, X., Wang, J., Nadiga, S., Tripp, P., Kistler, R., Woollen, J., Behringer, D., et al., 2010. The NCEP climate forecast system reanalysis. Bulletin of the American Meteorological Society 91 (8), 1015-1057.

Saha, S., Moorthi, S., Wu, X., Wang, J., Nadiga, S., Tripp, P., Behringer, D., Hou, Y.-T., Chuang, H.-y., Iredell, M., et al., 2014. The NCEP climate forecast system version 2. Journal of Climate 27 (6), 2185-2208.

Schiller, A., Oke, P. R., Brassington, G., Entel, M., Fiedler, R., Griffin, D. A., Mansbridge, J. V., 2008. Eddy-resolving ocean circulation in the Asian-Australian region inferred from an ocean reanalysis effort. Progress in Oceanography 76 (3), 334-365.

Smagorinsky, J., 1963. General circulation experiments with the primitive equations. Monthly Weather Review 91 (3), 99-164.

Willmott, C. J., 1981. On the validation of models. Physical Geography 2 (2), 184-194.

Wyrtki, K., 1960. The surface circulation in the Tasman and Coral Seas, Aust. CSIRO Div. Fish. Oceanogr. Tech. Pap. No. 8. 